\title{
برامج إدارة الاستشهادات المرجعية
}

\section{أحمر عبر الله حسين رزق}

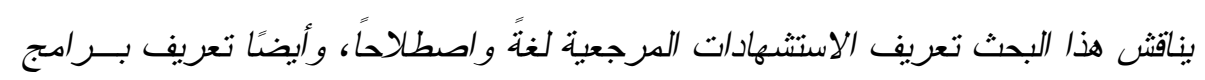

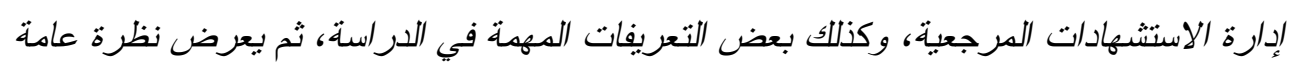

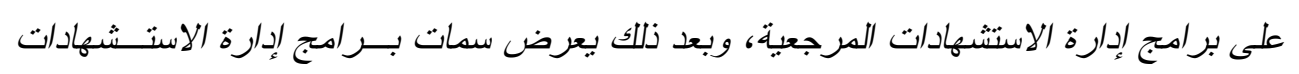
المرجعية، وكذلك الأنظمة المختلفة لإدارة المراجع، وكذلك مميزات وعيوب ثلإدك الأنظمة، وأخيرًا يُلْقِى عرض لنطبيقات الاستشهادات المرجعبة والصباغات المريكلة للاستشهادات المرجعية.

Abstract

This paper discusses the definition of reference citations in both language and terminology, as well as the definition of reference citations management programs, as well as some important definitions in the study. It then presents an overview of the reference citations management programs and then presents the features of the reference citations management programs as well as the different reference management systems, And finally, a presentation of the applications of reference citations and structured formulations of reference citations.

$$
\begin{aligned}
& \text { يعد الاستشهاد المرجعي أساس عملية على صياغة الاستشهادات المرجعية للبحـث } \\
& \text { البحث العلمي وكتابــة البحــوث و الرســائل العلمي أثناء كتابته. } \\
& \text { وتتألف عادة تلاك البر امج من قاعــدة } \\
& \text { بيانات و التي تُككن مــن تـسجيل البيانــات }
\end{aligned}
$$

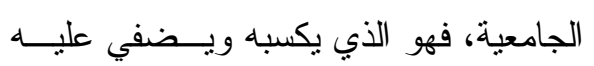

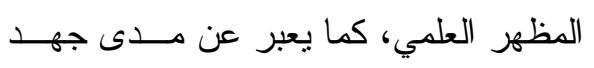

$$
\begin{aligned}
& \text { البيليوجر افية للمر اجع بها، فبمجرد تـسجيل } \\
& \text { الباحث وقر اعته ودقة استيعابه وقدرته فــي }
\end{aligned}
$$

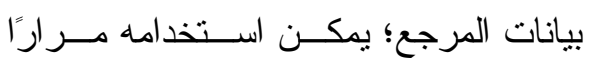

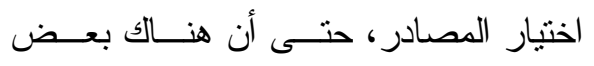

$$
\begin{aligned}
& \text { وتكر ارًا في توليد الاستــشهادات المرجعيــة } \\
& \text { الجامعات لها أسلوبها الخاص بها في إتبـــاع } \\
& \text { بأور اق العمل، كما تحتوي تللك البر امج على } \\
& \text { نشر أبحاثها أو رسائلها في مجلاتها العلمية. } \\
& \text { نظام قو ائم انتقائية لأدلة صياغة الاستشهادات } \\
& \text { ومع النطور السريع في الأدبيات العلمية كان } \\
& \text { من الضروري وجود بر امج تساعد الباحثين }
\end{aligned}
$$


عرض الاستــشهادات المرجعيــة بالــشكل المناسب، وتمكنك من استير اد أدلة صـــياغة استثهادات مرجعية أخرى، كما أنها أيــضًا تمكنك من إنشاء أدلة صـــاغة استــشهادات ات مرجعية جديدة. وتغطي البر امج جميع أنواع لئاه

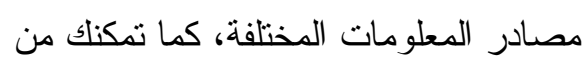

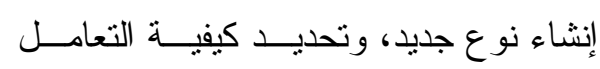

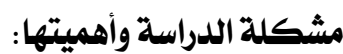

مع تز ايد دور البحـــث العلمــي فـي

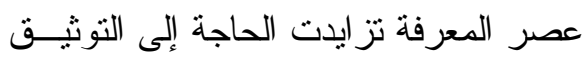

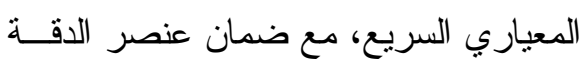

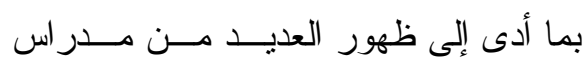
الاستشهادات المرجعية وأدلتها، وما تبع ذلك

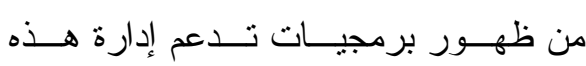
الاستشهادات، وتعددت هذه البر امج ور اجت بشكل تجارى. وفي ظل التطور السريع لتلك ونك

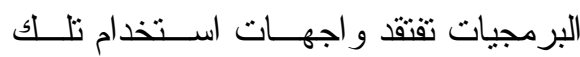
البر امج إلى اللغة العربية، وكـــلك صـــياغة الاستشهادات في أوراق العمل.

و هو ما جعل در استة هذه البرمجيــات

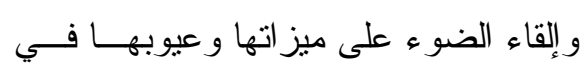

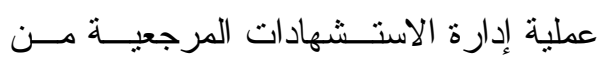
الأهمية بمكان لحل مشكلات إدارة صـــياغة الدانة

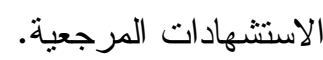

و المطلوبة من قبل الناثــرين أو المجــلات العلمية. و التي تتيح تغيير نمط الاستشهادات في ورقة العمل حسب الحاجة. أغلب برمجيات إدارة الاستـشهادات

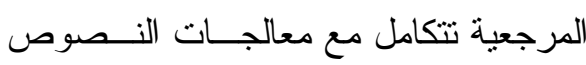
المختلفة، بحيث يمكن إنتاج قائمة المر اجـع معاته لئح Reference List

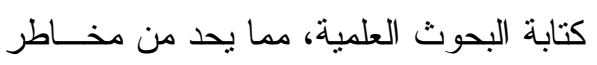

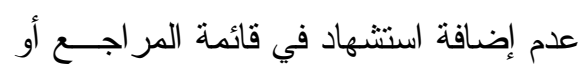

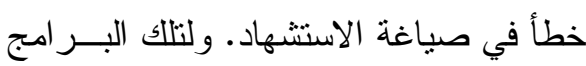
أيضًا القدرة على استنير اد بيانــات مــــادر المعلومات من قو اعد البيانات البيليوجر افيـــة

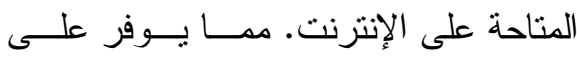
الباحث الوقت و الجهد في تجميع وصــياغة تلك الاستشهادات.

وتتتوع ع أساليب إتاحسـة بـــر امج إدارة

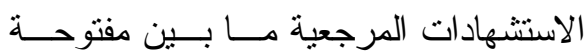

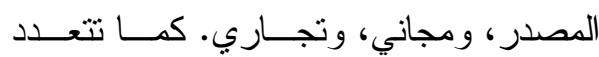

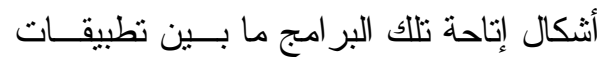

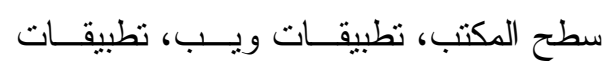
هجين (تطبيقات سطح المكتــب وتطبيةــات

$$
\text { ويب). }
$$

وتحتوي تللك البر امج على مجموعــة

من أدلة صياغة الاستـشهـادات المرجعيــة المختلفة Style Guides التي تمكـن مـن 


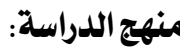

تعتمد الدر اسة على المنهج المـسحي

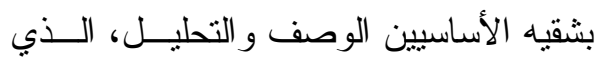
يعتمد على تجميع الحقائق و المعلومــات ثـــ

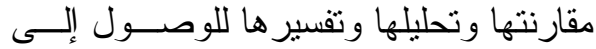

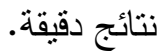

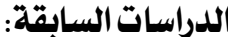

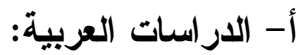

كثفت المراجعة العلمية بأنه يوجد العديـــ من الدراسات العربية في مجــال صــياغة الاستشهادات المرجعية ومن أهمها: الدر اسة التي قام بها (النجار)(') فــي عام I . . Y، حيث هدفت هذه الدر اسة إلـى

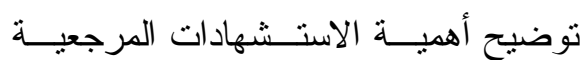
باعتبار ها مكونا أساسيًا من مكونات البحــث

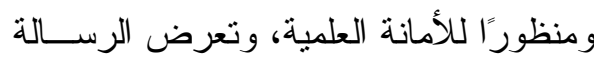
بالوصف و التحليل استخدامات أنماط صياغة الاستشـهادات المرجعية، سو اء كانت داخــل

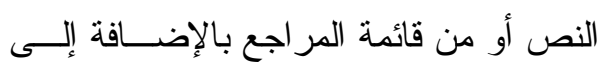

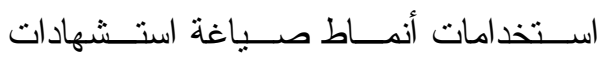

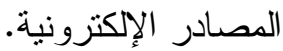

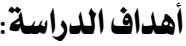

تسعى هذه الدراسة إلى تحقيق ما يلي:

() التعريف بنظم إدارة المر اجع ومميـز ات

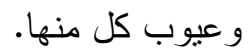

r التعريف ببـــر امج إدارة الاستـشههادات

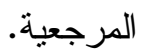

r) التعريــــف بتطبية المرجعية.

ع) التعريف بوظائف و عمليات بر امج إدارة الاستشهادات المرجعية.

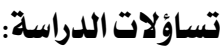

يمكن تحقيق أهداف الدراســة مــن خــلد الإجابة على التساؤلات التالية: ( ) ما هي نظم إدارة المراجع؟ Y) ما هي مميز ات و عيوب كل مسـن نظــــ إدارة المر اجع؟

r) ما هـي بــر امج إدارة الاستـشـهادات

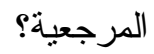

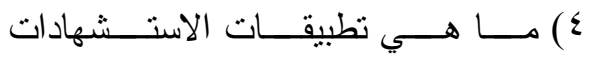
المرجعية؟

0) ما هي الوظائف و العمليات المختلفة التي

تقوم بهـــا بــر امج إدارة الاستـشـهادات المرجعية؟ 


$$
\begin{aligned}
& \text { نظام APA - نظام CBE - نظـــام دليـل }
\end{aligned}
$$

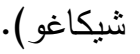

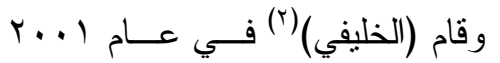

$$
\begin{aligned}
& \text { أما بالنسبة للار اســات العربيــة فـي } \\
& \text { مجال بر امج إدارة الاستشهادات المرجعيــة فــة }
\end{aligned}
$$

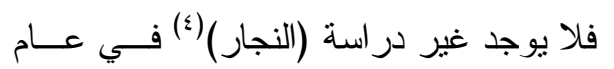

$$
\begin{aligned}
& \text { T . . T، وتهدف هذه الدر اسة إلى التعريــــ }
\end{aligned}
$$

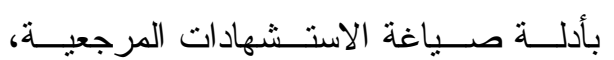

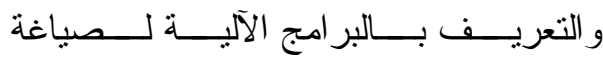

$$
\begin{aligned}
& \text { الاستشهادات المرجعية، ومعرفة أفضل هذه } \\
& \text { البر امج التي يمكن استخدامها فــي صـــياغة } \\
& \text { الاستشهادات المرجعية. وتشتمل هذه الدراسة } \\
& \text { على خمسة بر امج لــصياغة الاستـشهادات } \\
& \text { المرجعية، و التي نم الحصول عليها بالفعـلـ } \\
& \text { من قبل الباحث، مع العلم بأن هذه البــــر امج }
\end{aligned}
$$

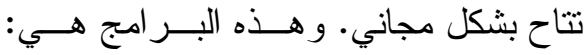

$$
\begin{aligned}
& \text { - Referencer TE - ScholarWord) } \\
& \text { - Endnote - Citation } 9 \\
& \text { Bibloexpress). ونوصل إلى عدم صدور } \\
& \text { هذه البر امج عن المؤسسات التـي صـــدرت ونس } \\
& \text { عنها أدلة صياغة الاستشهادات المرجعيـــة. } \\
& \text { (4) محمد محمد النجار، "البرامج الآلية لصباغة } \\
& \text { الاستشهادات المرجعية: دراسة تحليلية مقارنة"ال، } \\
& \text { في مهنة المكتبات و إلمعلومات في مصر بلئ بلين }
\end{aligned}
$$

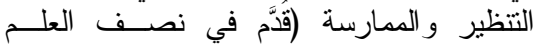

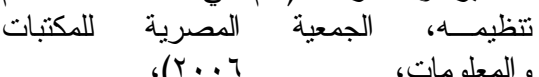

$$
\begin{aligned}
& \text { www.elaegypt.com/DownLoads/5.pp } \\
& \text { القاهرة: المنظمة العربية للنتمية الإدارية - العية }
\end{aligned}
$$

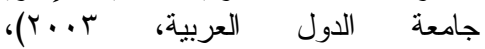




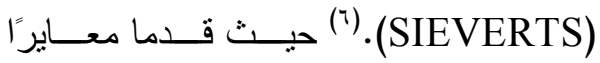

$$
\begin{aligned}
& \text { ومحاور للمقارنة بين نللك البــر امج و التــي } \\
& \text { اعتمدت عليها العديد من الدر اسات فيما بعد. }
\end{aligned}
$$

(6) EG SIEVERTS et al., "SOFTWARE FOR INFORMATION-STORAGE AND RETRIEVAL TESTED, EVALUATED AND COMPARED .2. CLASSICAL RETRIEVALSYSTEMS," Electronic Library 9, no. 6 (December 1991): 301-318.

EG SIEVERTS and M. HOFSTEDE, "SOFTWARE FOR INFORMATIONSTORAGE AND RETRIEVAL TESTED, EVALUATED AND COMPARED .1. GENERAL INTRODUCTION," Electronic Library 9, no. 3 (June 1991): 145-154.

EG SIEVERTS et al., "SOFTWARE FOR INFORMATION-STORAGE AND RETRIEVAL TESTED, EVALUATED AND COMPARED .3. END-USER SOFTWARE," Electronic Library 10, no. 1 (February 1992): 5-19.

EG SIEVERTS, M. HOFSTEDE, and BO GROENIGER, "SOFTWARE FOR INFORMATION-STORAGE AND RETRIEVAL TESTED, EVALUATED AND COMPARED .4. INDEXING AND FULL-TEXT RETRIEVAL PROGRAMS," Electronic Library 10, no. 4 (August 1992): 195-208.

EG SIEVERTS et al., "SOFTWARE FOR INFORMATION-STORAGE AND RETRIEVAL TESTED, EVALUATED AND COMPARED .5. PERSONAL INFORMATION MANAGERS, HYPERTEXT AND RELEVANCE RANKING PROGRAMS," Electronic Library 10, no. 6 (December 1992): 339 357.

EG SIEVERTS et al., "SOFTWARE FOR INFORMATION-STORAGE AND RETRIEVAL TESTED, EVALUATED AND COMPARED .6. VARIOUS ADDITIONAL PROGRAMS," Electronic Library 11, no. 2 (April 1993): 73-91. =

$$
\begin{aligned}
& \text { وتغطــى جميـــع البــر امج أدلـــة صـــياغة } \\
& \text { الاستشهـادات المرجعيــة باســتشناء برنـــامج } \\
& \text { Endnote و لا تغطى هذه البر امج كاملـــة } \\
& \text { جميع مصادر المعلومات الواردة فـــي أدلـــة } \\
& \text { صياغة الاسنشهادات المطبو عــة. وجمبــع } \\
& \text { البر امج تدعم اللغة العربية باستثناء برنــامج } \\
& \text { Referencer TE } \\
& \text { ScholarWord } \\
& \text { ب- الدر اسات الاجنبية: } \\
& \text { كما كثفت المر اجعـــة العلميــة بــأن } \\
& \text { الدر اسات المقارنة لبر امج إدارة الاستشهادات } \\
& \text { المرجعية قد بدأت في الفترة ما بين أواخـر }
\end{aligned}
$$

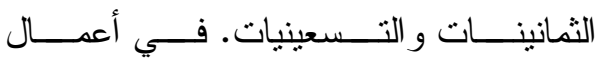

$$
\begin{aligned}
& و^{(0)} \text { (Nieuwenhuysen) }
\end{aligned}
$$

(5) P. NIEUWENHUYSEN, "A Bibliography of Text Information Management Software for Ibm Microcomputers and Compatibles," Electronic Library 6, no. 4 (August 1988): 264-314.

P. NIEUWENHUYSEN, “A BIBLIOGRAPHY OF TEXT INFORMATION MANAGEMENT SOFTWARE - 1989 UPDATE," Electronic Library 7, no. 6 (December 1989): 405-426.

P. NIEUWENHUYSEN, "A Bibliography of Text Information Management Software for Ibm Microcomputers and Compatibles," Electronic Library 8, no. 4 (August 1990): 254-278. 
يدويًا. و الثانية، تكامل تلك البر امج مع معالج

النصوص حيث إنها تـــوفر الوقــت الــلازم

لتوثيق المر اجع في أور اق العمــل، وكــــللك

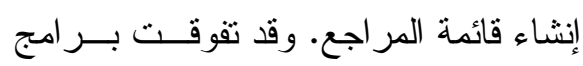

Pro- و Papyrus ondnote Plus

Reference Manager g cite

غير هم من البر امج محل الدر اسة. وتتقـــاوت

هذه البر امج فيما بينها في سهولة الاســتخدام

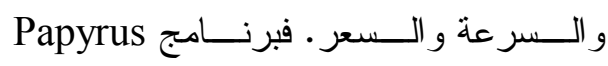

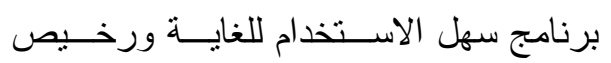

الثثن، ولكنه أقل في السرعة مــن الثناثـــة

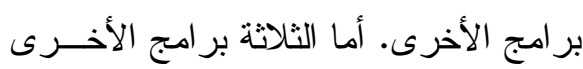

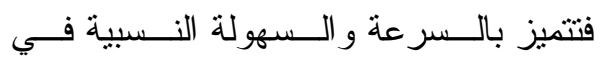

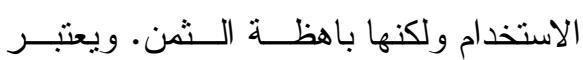

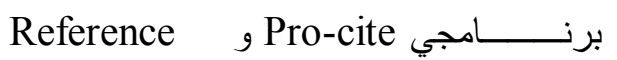

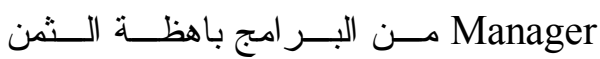

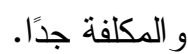

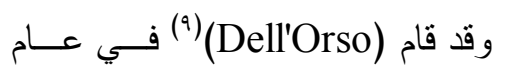

999 199عل قائمة مر اجعــة لبـــر امج إدارة

الاستشهادات المرجعية وطبقها في أول الأمر

على برنامجين. ثم استمر التحديث الـدوري

(9) Francesco Dell'Orso, "Bibliography Management Software: Analysis and Comparison of Some Packages", 2010

http://www.burioni.it/forum/dellorso/ bms-dasp/text/index.html.
وقد قام (Moore)( 1991

بتحديد المعايير الو اجب توفرها فــي قاعـدة

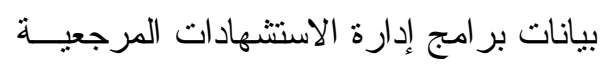

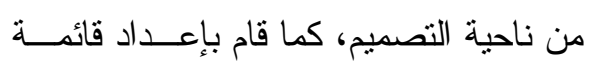
مر اجعة لتقبيم تلك البر امج.

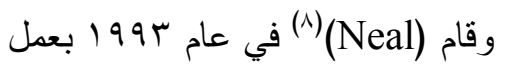

در اسة مقارنة لعدد ب ا مــن بـــر امج إدارة

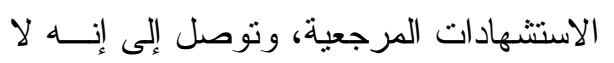

يوجد ما يسمى بأفضل برنامج. فمن الو اضح

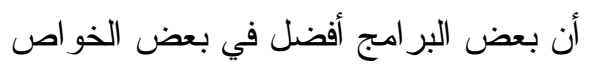

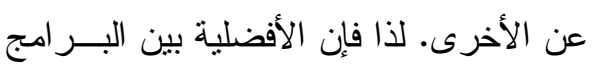

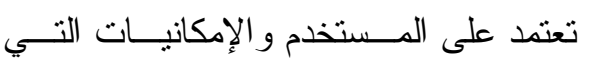
يحتاجها. و هناك خاصيتين ور اء تلك البر امج

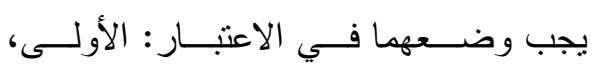

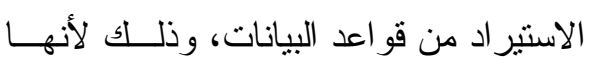

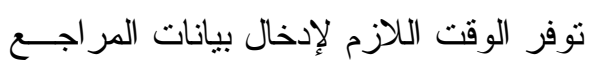

$=$ EG SIEVERTS and M. HOFSTEDE, "SOFTWARE FOR INFORMATIONSTORAGE AND RETRIEVAL TESTED, EVALUATED AND COMPARED .7. WHAT TO CHOOSE, OR THE PURPOSE OF IT ALL," Electronic Library 12, no. 1 (February 1994): 21-22.

(7) C. Moore, "Personal Reference Management Software-how to Evaluate It?," Health Libraries Review 8, no. 1 (1991): 4-10.

(8) P. R. Neal, "Personal Bibliographic Software Programs: A Comparative Review," BioScience 43, no. 1 (1993): 44-51. 


$$
\begin{aligned}
& \text { برنامج Biblioscape افضل فــي البحــث } \\
& \text { وأرخص في الثمن ويجــري لـــه التحــديث } \\
& \text { المستمر بسر عة ليعـزز البرنــامج دوريًا }
\end{aligned}
$$

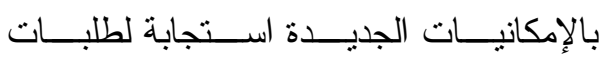

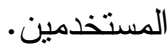

$$
\begin{aligned}
& \text { وقام (Omar)(') } \\
& \text { ببناء دراسة علــى أن هنــالك حاجــة مــنـ } \\
& \text { University of Technology } \\
& \text { بر امج إدارة الاستشهادات المرجعية. كما أن }
\end{aligned}
$$

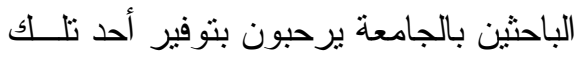

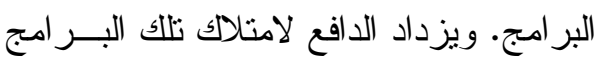

$$
\begin{aligned}
& \text { من قبل المستخدمين الفعليين لتلك البر امج في }
\end{aligned}
$$

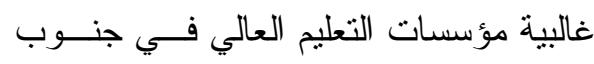

$$
\begin{aligned}
& \text { أفريقيا. وقد أجرى المقارنة على عدد خمسة } \\
& \text { من بر امج إدارة الاستــشهادات المرجعيــة. }
\end{aligned}
$$

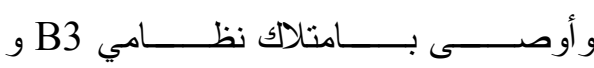

$$
\begin{aligned}
& \text { RefrenceManager } \\
& \text { RefrenceManager } \\
& \text { الشبكي و الغير موجـــودة بأغلــبـ البـــر امج إنه } \\
& \text { الأخرى. كما أشار بأنه يمكن شر اء عدد قليل }
\end{aligned}
$$

(11) Yunus Omar, "Comparative Analysis of Selected Personal Bibliographic Management Software (PBMS) with Special Reference to the Requirements of Researchers at a University of Technology" (Stellenbosch: University of Stellenbosch, 2005).
ليضيف محاور جديدة للمقارنة وكنلك إضافة بر امج جديــدة. وصــلت عــد الدر اســات المقارنة التي قام بها بصفة مستمرة إلى 11 در اسة وذللك حتى عام • · •r. ومن الملاحظ أن Dell'Orso لم يقدم تفضيلات لأي من البر امج في دراسته ولكنه يشير إلى أن أفضل برنامج هو الــذي يلبــي احتياجات المستخدمين. ويتضح من در اســته

أن برنـــــامجي Endnote و Reference Manager لهما أفضل الإمكانيات مقارنـــة

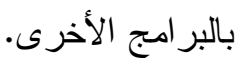

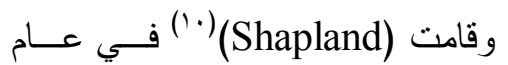

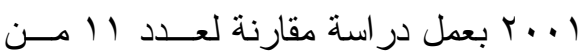

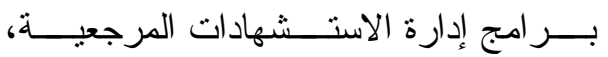
وتوصلت إلى أن أفضل برنامجين من بر امج Endnote إدارة الاستشهادات المرجعية هما لمان

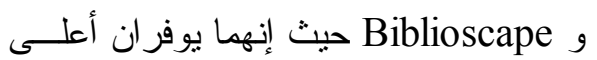
درجة من السهولة في الاســتخدام ومرونــة

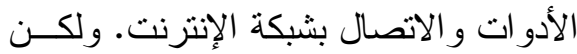

(10) Maggie Shapland, "Evaluation of Reference Management Software on NT (comparing Papyrus with ProCite, Reference Manager, Endnote, Citation, GetARef, Biblioscape, Library Master, Bibliographica, Scribe, Refs", 2001, http://eis.bris.ac.uk/\%7Eccmjs/rmeva 199.htm. 
قو اعد البيانات، فهارس المكتبات، محركــات البحــث، المــستودعات الرقميــة) إمكانيـــة التصدير المباشر Direct Export و التـي

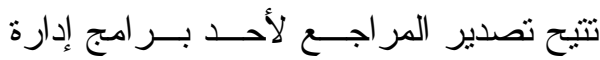

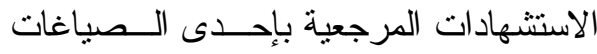

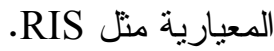

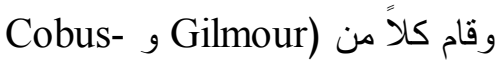

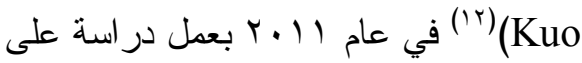

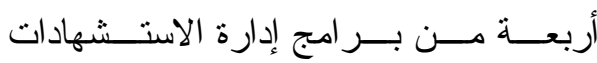
المرجعية، وقد ر اعيا اختيار نظامين مبنيــان

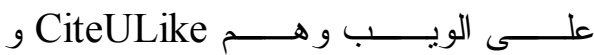
Refworks ونظامين آخرين من تطبيقـات

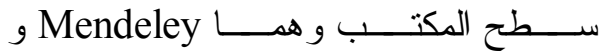
Zotero البر امج هو Refworks لدقة الاستـشهادات المرجعية به، التحديث المستمر له، كمــا أن له العديد من الفيديو هات التعليمية اكثر مـن أي برنامج آخر في البرامج الثناث الأخرى. ظهــرت الخــدمات و التــي تــسمح للمستخدمين بمشار كة محتويــات مكتبـــاتهم

(12) Ron Gilmour and Laura Cobus-Kuo, "Reference Management Software: A Comparative Analysis of Four Products," Issues in Science and Technology Librarianship, no. 66 (2011), http://www.istl.org/11summer/refereed2.html.
من نسـخخ برنــامج RefrenceManager وذللك لاستير اد المر اجع من المصادر الكبيرة

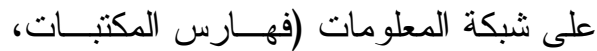

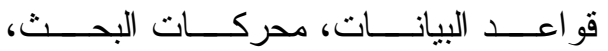
المستودعات الرقمية). تلاكك المر اجع يمكـن مئن استير ادها في برنـــامج B3 فهـــو برنــامج مجاني يمكن للجميــع اســتخدامه للمعالجـــة

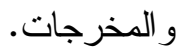

وما سبق يشير إلى أنه وحتهـى ذلـــــ

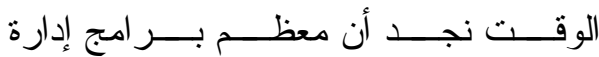
الاستشهادات المرجعية لا تتيح الاستير اد من المصادر الخارجية. وكذللك لا نتيح خاصــية المشاركة. كما أن أسس نطوير تلك البر امج قد تغيرت نتيجة لظهور العديد من المعسايير و الخاصة، إما بالبحث و الاسترجاع أو بتبادل المعلومات و الخاصة بنلك البـــر امج. فعلــى Open URL سبيل المثــال ظهــر معيــار

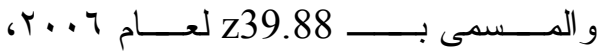
وحاويات البيانات الخاصــة بــهـ Context Objects مما أدى لظهور COinS كائنات المحتوى بعنـــر span. وكـــللك ظهــور صياغة التبـــادل المعياريــة RIS Format، و هي طريقة معياريــة لــصياغة المر اجـع تسنطيع معظم البرامج الآن التعامل معهــا، ونتيح العديد من المصـادر الخارجية (مثـــل: 
معايير للاختيار (متل: سعة التخزين، إمكانية إضافة التعليقات، إمكانيات البحث...إلخ). من خلال العرض السابق للاراســات التــي توافرت للباحث يتضح أن:

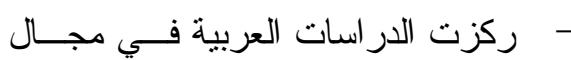

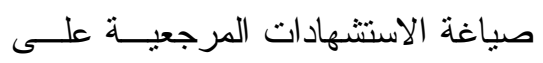
توضيح أهمية الاستشهادات المرجعيــة

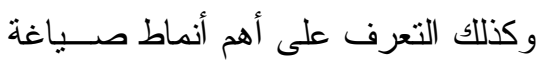
الاستشهادات المرجعية. ركزت جميع الدراسات الأجنبيــة فــي مجال مقارنة بر امج إدارة الاستشهادات

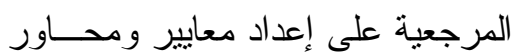
للمقارنة بين تللك البر امج إما لمكوناتهـــا و العمليات الأساسية التي تقوم بها، و إما

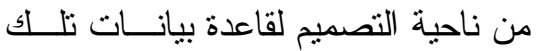

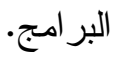

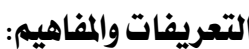

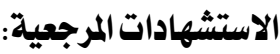

\section{يمكن تعريف الاستثهادات المرجعية}

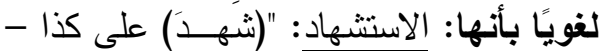

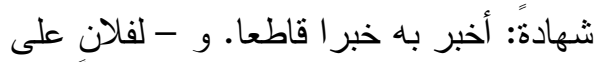
فلان بكذا: أدى ما عنده من الثهادة. و - بالله

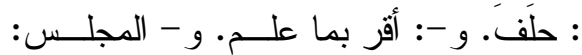

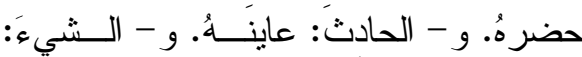
عاينَهُ. ويقال: شهََ على شهادة غيره، وشهر

الثخصية في بــر امج إدارة الاستــشهادات المرجعية من مر اجع في موضو عات بحثهم. مما يسمح بتوسيع قاعدة انتشار تلك المر اجع وسـهولة حصول أقر انهم في نفـس المجــال

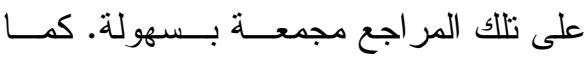
يمكنهم التفاعل مع غير هم من الباحثين فــي هذا المجــال. وتــــم الدر اســات الــــابقة وتوصياتها مجموعة كبيرة من محاور وبنود المقارنة و التي يمكن الاستعانة بها في إعداد

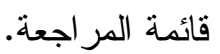
ومما سبق يتضح أن عمليــة اختيــار

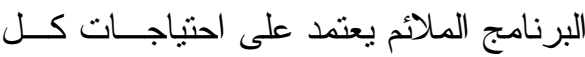
مستخدم، ولكل برنامج من هذه البر امج نقاط

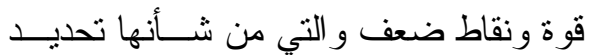
اتجاهات فئة المستخدمين بالسلب أو الإيجاب على أحد تلك البر امج. فعلى سبيل المثــال:

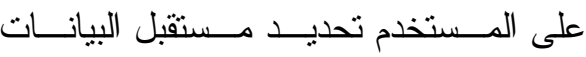
المخزنة لديه، هل هي من أجل ورقة عمـلـ أو مشروع واحد حيث ستكون قائمة مرجعية

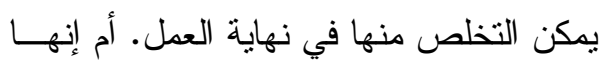
مكتبة من المر اجع و التي يكونها المـستخدم من أجل البحوث الجارية. ففي الحالة الأولى لهي "سهولة الاســتخدام" هـــو معيــار اختيـــار

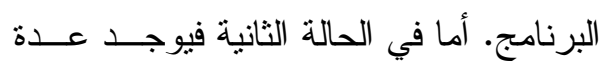


(Citation ) و عرفه علــى أنـــه: "استـشهاد مرجعي أو إحالة إلى النص أو الفقرة التـي لـ التي

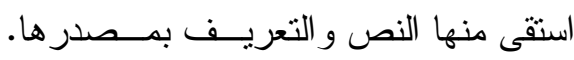

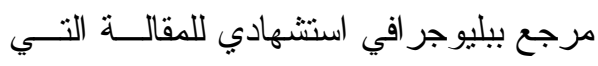
أخذت منها عدة أسطر نصوص معلوماتبـــة كإحالة تعريفية بمصدر ها".. (T) في حين ورد تعريف الاستـشهادات

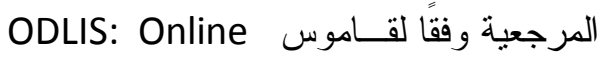
Dictionary for Library and Information Science

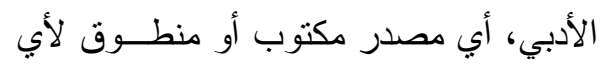
سلطة. أو أي كلمات حرفية لأي متحدث أو أو

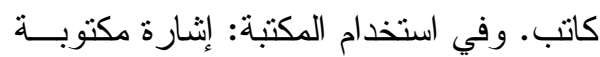
لعمل محدد أو جزء من عمل (كتاب، مقالة،

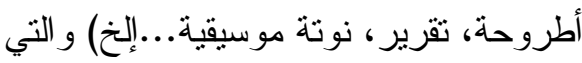

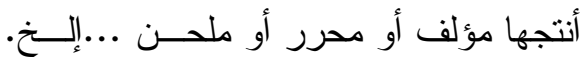

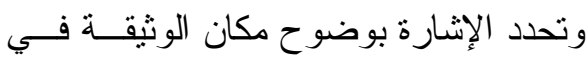

العمل". (lv)

وعَرَّن محمــــ النجـــار الاستـشهادات

المرجعية على أنها "إثبات حق الآخرين في شكل

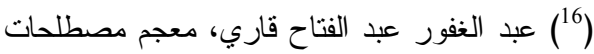
المكتبات و المعلومات (الرياض: مكتبة المبات الملك فهر

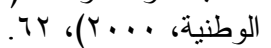

$\left({ }^{17}\right)$ Joan M Reitz, Western Connecticut State University, and Libraries Unlimited Inc, "Online Dictionary for Library and Information Science ODLIS", 1996, http://www.abcclio.com/ODLIS/odlis_C.aspx?\#citati on.
بما سمع. (اسنتَتَهْرَ) الرجل فلانًا: طُلب منـــهـ

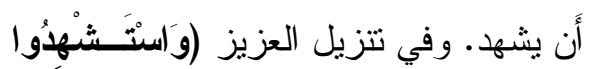

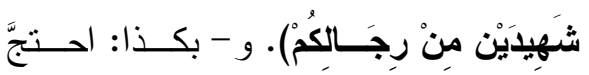

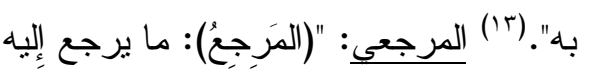
في علم أو أَدب، من عالم أو كتاب.(محدثة).

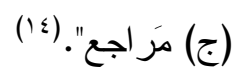

\section{بينما يمكن تعريــف الاستـشهادات}

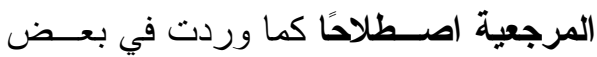

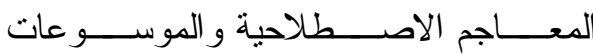
و الدر اسات العلمية، ففي قاموس البنهــاوي الموسوعي: ورد مصطلح (استشهاد مرجعي تحت مصطلح Citation) و عرفه على أنه:

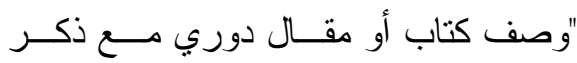

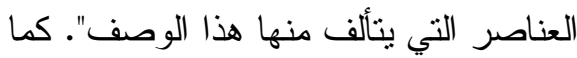
يعطي القاموس تعريفا آخر تحت مــصطلح

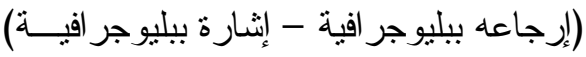
ويعرفها على أنها: "إثنارة إلى نص أو جزء من نص تعرف وتصنف بيليوجر افيا مصدر الوثنقة". (10)

$$
\begin{aligned}
& \text { كما ورد فـي معجـم مـصطلحات }
\end{aligned}
$$

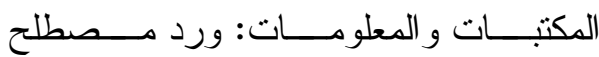

$$
\begin{aligned}
& \text { (الاستــشهاد المرجعــي تحــت مــصطلح }
\end{aligned}
$$

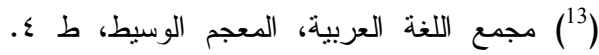

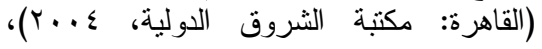

$$
\begin{aligned}
& \text { (ال) } \\
& \text { (15) شعبان خليفة، قاموس البنهاوي الموسوعي في المبان }
\end{aligned}
$$

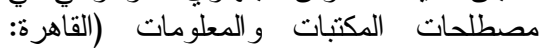

$$
\begin{aligned}
& \text { العربي للنشر و النوزيع، .99 (1))، זو. }
\end{aligned}
$$




$$
\begin{aligned}
& \text { البيليوجر افية وصياغتها في شكل مقنن مــن } \\
& \text { أنماط صياغة الاستشهادات المرجعية".(r) }
\end{aligned}
$$

Alligood \& Skidmore "BRMS" Bibliographic البليوجر افية (Reference Management Software وعرفاها على أنها "أداة معقــدة ومنطــــورة لإدارة المعلومات. ولتلك الأداة القدرة علـى

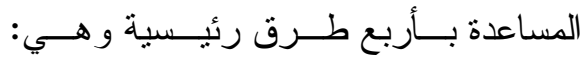
الاسترجاع، وتتظــــم وتخـزين المر اجـع، و إدر اجها في الثقارير باستخدام نمط استشهاد

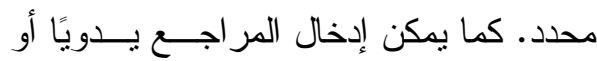
تحميلها في قاعدة بيانات تلك البر امج بحيـــث تتكامل المر اجع بداخل التقرير لإنشاء قائمــة

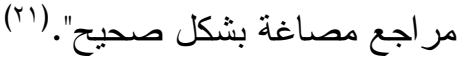

(20) محمد محمد النجار، "البرامج الآلية لصياغة

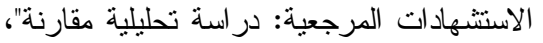

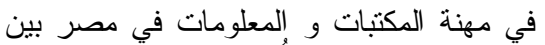

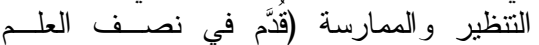

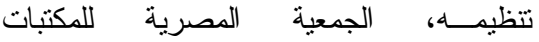
و المعلومات، www.elaegypt.com/DownLoads/5.pp

$\left({ }^{21}\right)$ Elaine Alligood, Becky Skidmore, and National Information Center on Health Services Research and Health Care Technology, "Etext on Health Technology Assessment (HTA) Information Resources", July 2003, http://www.nlm.nih.gov/archive/2006 0905/nichsr/ehta/chapter 17.html.

$$
\text { صي عمله". (^) معنرف بها برتضيها الباحث أو المؤلف }
$$

كما عَرَّف محمد الخليفي الاستـشهاد

Citation التي رجع إليها الباحث في در استه، لتمكـين القارئ من الرجوع إليها بيسر وسهولة". (9.) ومن التعريفات السابقة يمكن تعريف

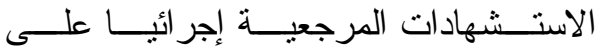
أنها: مجمو عة من البيانـــات البيليوجر افيــة لأحد مصادر المعلومات، و التي نم صياغتها

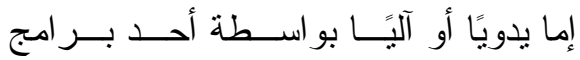

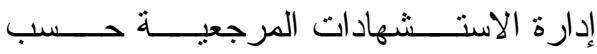

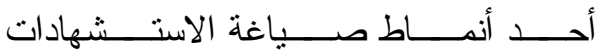

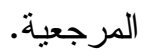
برامج إدارة الاستشهادات المرجعية: اختلفت تسميات تلك البــر امج فقـط أطلق عليها محمد النجار (البـــر امج الآليـــة لصياغة الاستشهادات المرجعية)، وعرفهــا

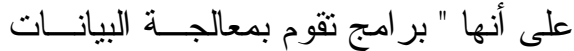

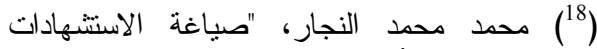
المرجعية" (أطروحة ماجستير، جامعة المنوفية، . $1 \leqslant$ ( $)$ ( r...)

(19) محمد صالح الخليفي، 'تؤثيق الاستشههادات المرجعية: دراسة تحليلية لمنهاج النشر في النئي بعض الدوريات"، مجلة مكتبة الملك فهية الوطنية ד، عدد ז (مارس 1. . ب): 199 


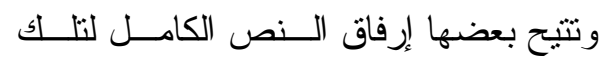
المر اجع، و البحث بأحد الحقول أو جزء عنها منها

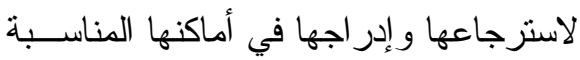
بداخل أور اق العمل حسب الصياغة المناسبة وإنبا

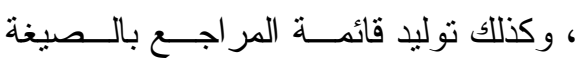
المناسبة حسب أنماط الاسنتهادات المختلفة.

Style أدلة أنماط صـياغة الاستـشهادات : Manuals

"فــي ظــلـل تعــدد أنمـــاط صـــياغة

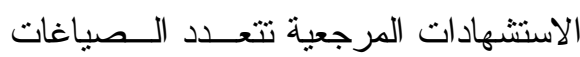

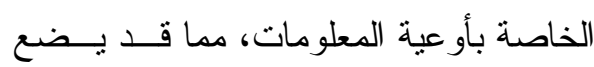

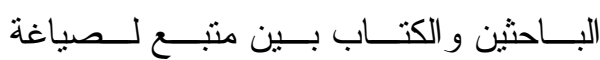
ومعارض للأخرى، وقد نتج هذا عن عـدم وجود صياغة مقننة للاستشهادات المرجعية ومات

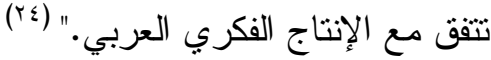

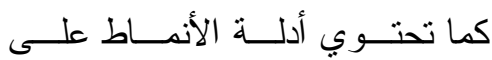
مجموعة من القو اعــــ الخاصــة بــصباغة

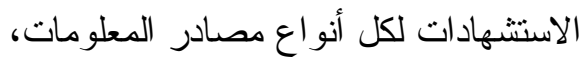

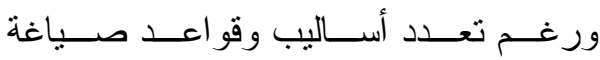

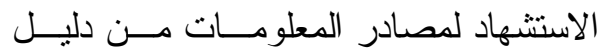
لآخر • إلا إنها تختلف في جو انب شكلية فقط. أما البيانات التي تذكر عن المــصدر فهـي الهـي تقريبا متفق عليها.(ro)

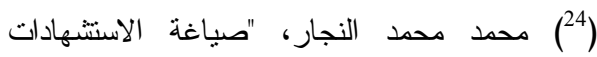

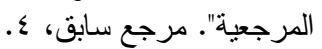

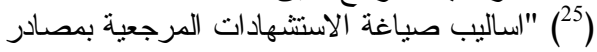
الانترنت: قائمة وبيليوجر افية"، cybrarians
بينمــــا أطلـــق عليهـــا Dell'Orso

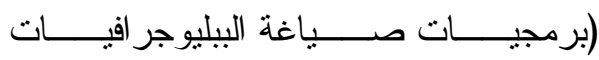

(Bibliography Formatting Software

$$
\begin{aligned}
& \text { و عرفها على أنها "مجموعة مــن البــر امج }
\end{aligned}
$$

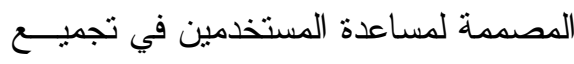

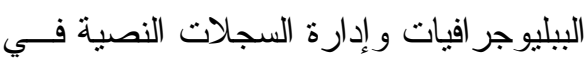

$$
\begin{aligned}
& \text { و احد أو أكثر من قو اعد البيانات".(rr) } \\
& \text { و أطلقت عليهــا Castilla (المــدير }
\end{aligned}
$$

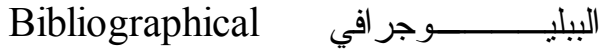
(Managers الأدو ات اللازمة لتسهيل عمليات جمع و إدارة وتتظيم وعــرض المر اجــع البيليوجر افيــة

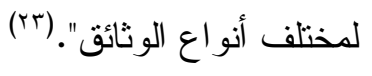

ومما سبق يمكن تعريف بر امج إدارة

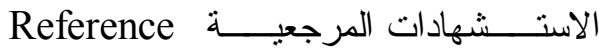
Management Software

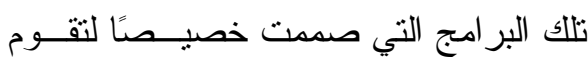
بعملية إدارة المر اجع عن طريــق الـسماح

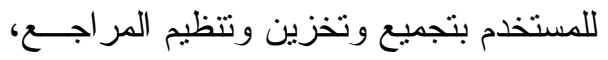

$\left({ }^{22}\right)$ Francesco Dell'Orso, "Bibliography Formatting Software: An Evaluation Template", 2007 , http://www.burioni.it/forum/orsbfs/text/index.html.

$\left({ }^{23}\right)$ Liuris Rodríguez Castilla, "Le Resulta Difícil Hacer La Bibliografía: Los Gestores De Referencias Bibliográficas Pueden Ayudarlo," Acimed 19, no. 2 (February 2009): 121. 


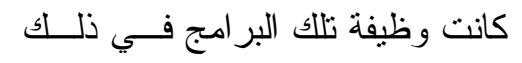

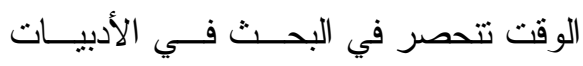

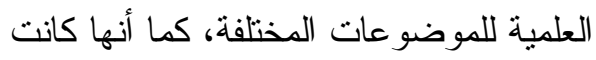

توفر الوقت و المجهود وكذلك التكلفة المادية،

كما أن المقالات الحديثة في الموضو عود كانت

تتوفر في تلاك البر امج قبل طباعتها بأسابيع،

فكان على الباحث أن يتعلم تقنيات اســتخدام

تللك البر امج. (بr)

كانت هناك محاو لات قليلــة لأعـــداد

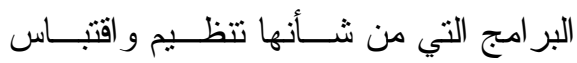

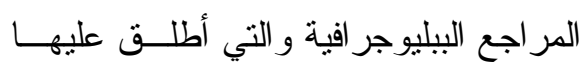

البرمجيات الببليوجر افية، فقد نم إنتاج اثثــان

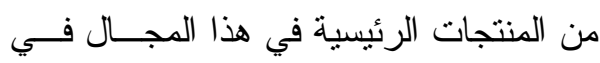

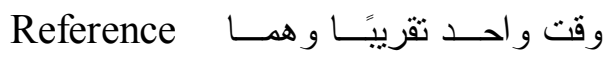

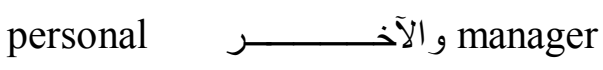

bibliographic reference

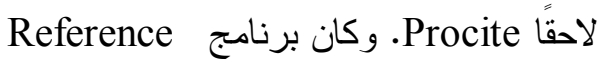
من بنات أفكار باحث في مجــال برنامج أمر اض الدم وهو Ernest Beutler مــدير

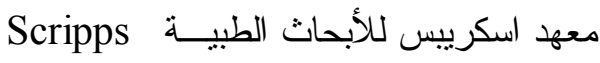

Research Institute وضعها Victor Rosenberg الأستاذ بكلية

$\left.{ }^{26}\right)$ Jud W. Gurney and Robert S. Wigton, "Computerized Reference

Management: Searching the Literature," American Journal of Roentgenology $147 \quad$ (September 1986): 641.
وبناءً على ما سبق فإنه يمكن الإثنارة

إلى أدلـــة الأنمــاط Style Manual بأنهــــاء مجمو عة من القو اعد لكتابة وتــصميم أور اق بات

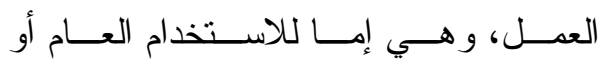
الاستخدام المحدد للنشر في منظمات أو حقل

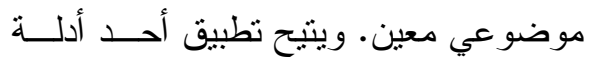
الأنماط التوحيد في الأسلوب وكذلك تتـسيق لطين

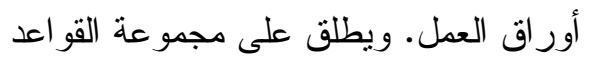
المحددة لكتابة وتصميم أور اق العمل من قبل مجيل منظمة معينة (نمط محلي House Style).

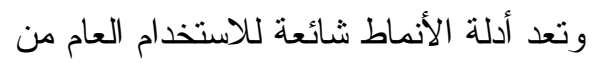
جمهور القــر اء و المــؤلفين، أو للاســـتخدام

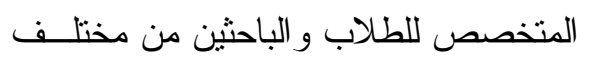
التخصصات الأكاديمية. تاريخ برامج إدارة الاستشهادات المرجعية: في بدايـــة الثمانينــات مــن القــرن العشرين وبعد ظهور أجهزة الحاسب الآلـي

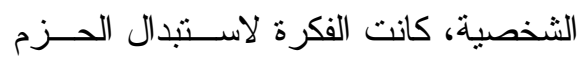
التقليدية لبطاقات المر اجع الببليوجر افية التي لئن كانت معيارًا لتتبع مصادر المعلومسـات فــي ليـي ذللك الوقت، إلى ملفــات إلكترونيــة علــى

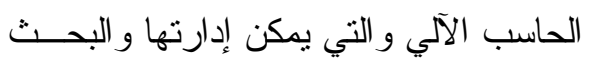
فيها بسهولة.

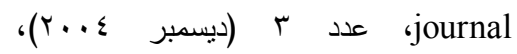
http://www.journal.cybrarians.info/in dex.php?option $=$ com_content\&id $=35$ 


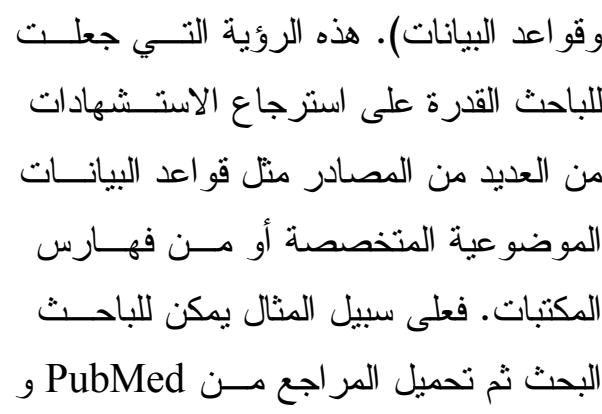

Chemical و Web of Science Abstract الكونجرس أو فهارس المكتبات الجامعية من

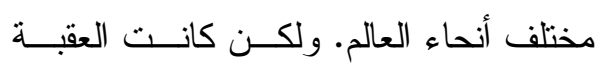
الرئيسية أمام تحقيق هذه الرؤية هي اختلاف

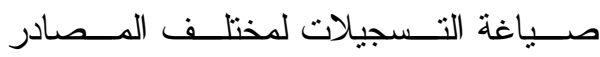

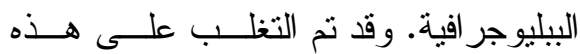

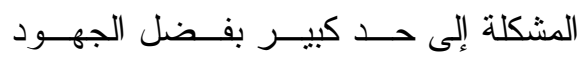
المشتركة لمطوري البرمجيــات الشخــصية

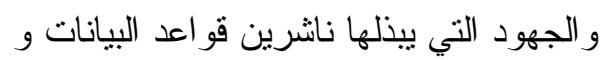

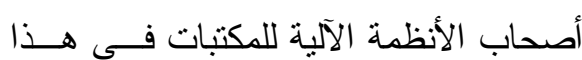

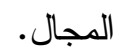

وتوفر معظم فهارس المكتبات الكبرى وقو اعـــــ البيانــات الآن صــــاغة تــسنطيع المنتجات البيليوجر افية الثخصية قر اءتهــا. ولكن في الغالب لم تكن تتوفر تلك الصياغة في باقي الفهارس وقو اعد البيانات؛ لذلك فقد تم بذل الكثير من الجهد في إعداد برمجيــات وهئ

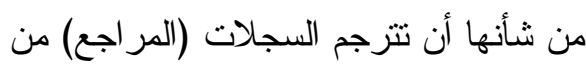
فهارس المكتبات وقو اعد البيانات إلى الــنظم الببليوجر افية الثخصية.
علوم المكتبات بجامعة مينتجان بالو لايــات

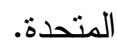
وفي وقت لاحق ظهر بالسوق برنامج Richard Niles و التي وضعها Endnote مدير شركة Niles Software. وتم شـــر اء كلاً من الثثلاثة منتجات في وقت لاحق مسن قبل Thomson Scientific. و ولاز الت تباع تلاك المنتجات حتى اليوم. وبالإضافة إلى ذلك وضعت Thomson Scientific اثنان مسن منتجات المبنية على الويـب Web-based في هذا المجال و هما RefViz و Endnote .web

قــــام Earl Beutler ابـن Ernest بالترويج التجاري لفكرة و الده بعد بيع شركته Research Information Systems Thomson Scientific التسعينيات و إنتاج برنــامج مــن المنتجــات

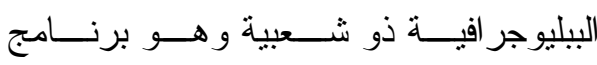
RefWorks برنامج RefWorks مملوك دو الآن من قبل ProQuest. ثم قام عدد مـن بـن مطوري البرمجيات بإنشاء مجموعــة مــن

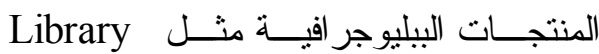
و Nota Bene و Paster .BibTeX

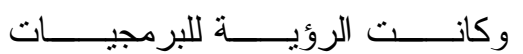

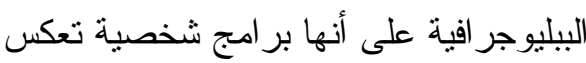

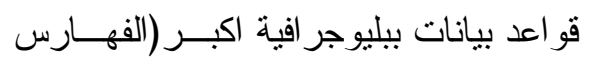




$$
\begin{aligned}
& \text { معالجة النصوص، إنما هم في حاجة لــنظم }
\end{aligned}
$$

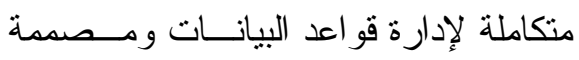

$$
\begin{aligned}
& \text { خصيصًا للسجلات البيليوجر افية. } \\
& \text { كما "إن نظم إدارة قو اعـــــ البيانــات }
\end{aligned}
$$

المعروفة منل Access أو File Maker لم

يتم تصميمها لتتاسب النطبيقات الببليوجر افية.

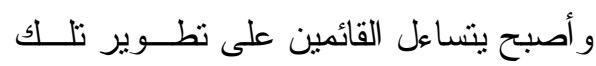

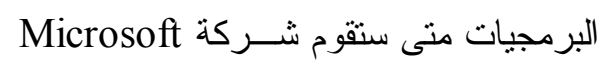
أو ناشري Word Perfect بإضافة خاصية إدارة المر اجع كخاصية جديدة في بر امجهم.

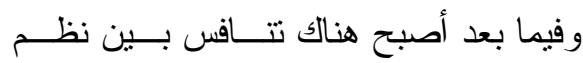

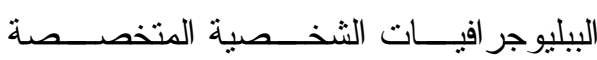

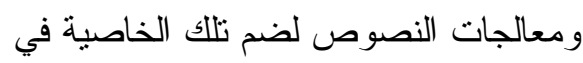

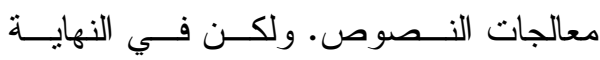
أصبحت نظم البيليوجر افيات الثخصية فئسة

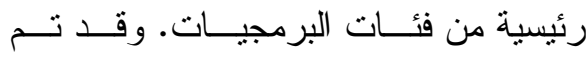
تضمينها في التعليم العالي وتدرس من قبــلـ

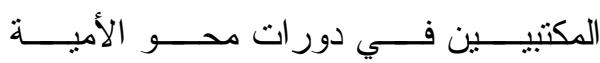
المعلومانية". (rv) ويلاحظ أن ظهور هذه البرمجيــات، وخاصة حزم البرمجيات المبنية على الويب

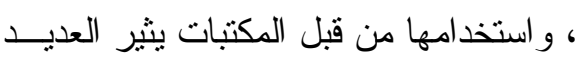

$\left.{ }^{27}\right)$ Dirk Schoonbaert and Victor Rosenberg, "Personal Bibliographic Systems (PBS)," Encyclopedia of Library and Information Sciences (London: Taylor \& Francis, 2010), 4128.
وقد اثتملت الرؤية المسنقبلية على أن الباحث قد يحتاج إلى جمع المر اجع في قاعدة

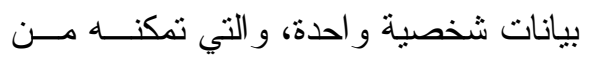

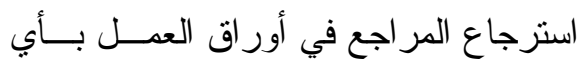

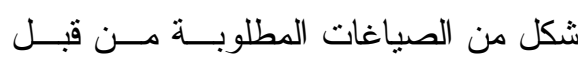

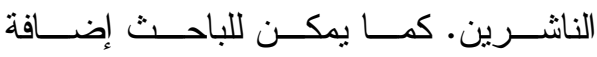

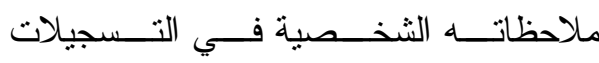
البيليوجر افية و التي تساعده في أثناء إعـــداد أوراق العمل. وبتطور التكنولوجيا وزيــادة

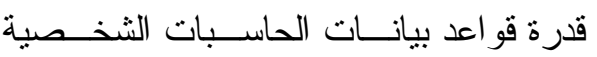

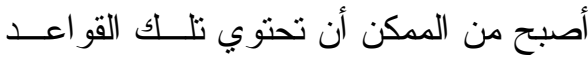

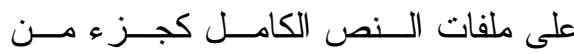
السجلات الببليوجر افية.

كان من المهم للأنظمة الببليوجر افيــة

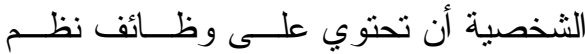
المؤسسات الكبيرة. فللمستخدم القدرة علـى في

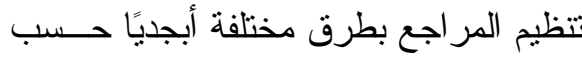

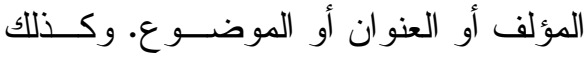
القرة على تكثيف البيانـات أو اســترجاع المعلومات من خلال البحث عن الكلمات في

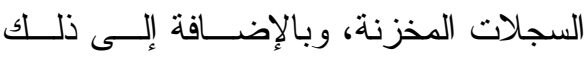
القدرة على إدر اج المر اجع فــي المسـتندات

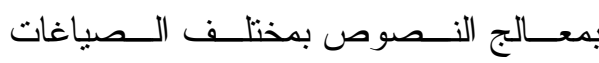
المطلوبة من قبل الناشرين.

منذ وقت مبكر أصبح مــن الو اضــح عدم حاجة المستخدمين للبر امج التــي تقــوم فقط بصياغة الببليوجر افيـات فــي بــر امج 


$$
\begin{aligned}
& \text { المعلومـــات المختلفــة (مثتـلـ: كتـــب، } \\
& \text { أطروحات، دوريات...إلخ). } \\
& \text { إرفاق ملفات للمراجع المخزنة: وذلك عـن } \\
& \text { طر يق: } \\
& \text { • إضـافة ملفات للمر اجع (مثتــل: PDF و } \\
& \text { صفحات الويب و صور ...إلخ). } \\
& \text { • عمل رو ابط فائقة بأماكن ثو اجد الــنص }
\end{aligned}
$$

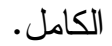

$$
\begin{aligned}
& \text { تنظيم و إدارة المراجع المخزنة: وذللك عـن } \\
& \text { طريق: } \\
& \text { • تتظيم المر اجع في عدة مجلــدات قابلــــة } \\
& \text { للبحث. } \\
& \text { • إضافة ملاحظات شخـــية وتعليةــات } \\
& \text { على المر اجع المختلفة. }
\end{aligned}
$$

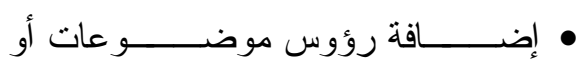

$$
\begin{aligned}
& \text { مصطلحات تكثيفيه للمر اجع. } \\
& \text { تكثيف ملفات النص الكامل. } \\
& \text { استرجاع المراجع المخزنــة : وذلــــ عـنـ } \\
& \text { طريق: } \\
& \text { • البحث المنطقي فـي حقــول الوصـــ } \\
& \text { المختلفة. مع إمكانية تحديد حدود البحث } \\
& \text { (مدى السنوات، نوع المصدر ...إلخ). } \\
& \text { • استعر اض المر اجع أبجديًا وفق رؤوس }
\end{aligned}
$$

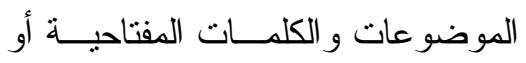

$$
\begin{aligned}
& \text { المؤلف أو السنة ...إلخ. }
\end{aligned}
$$

من القضايا ذات الطابع العلمي و الأخلاقـي. "فاستخدام هذه الأدو ات قد تخفف بعض الملل من فعاليات محو الأمبية المعلوماتية وكــذلك الك إتاحة الفرصة أمام الطلاب للتركيز على فهم

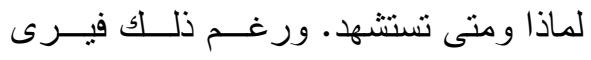
المكتبيون أن الطلاب لن يتعلمو اكيفية عمل استشهاد صحيح إذا لم يتعلمو ا كيفية القيــام بذللك يدويا". (r^)

\section{سمات برامج إدارة الاستشهادات المرجعية:}

تعددت سمات نلاك البر امج وتختلــــ

تلاكك السمات من برنامج لآخر ولكن تجنمــع تلاكك البر امج على مجموعــة مــن الـسمات

$$
\text { الأساسية وهي: }
$$

إدخال وتخزين المراجع: وذلك عن طريق:

• استنير اد المر اجع من المصادر المتاحـــة

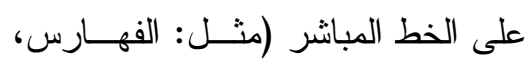

قو اعد البيانات، الموسوعات، مجمو عات

المشاركة، صفحات الويـــب المختلفــة

$$
\text { •إل... }
$$

• الإدخال البدوي لحقول الوصف المختلفة

(منثل: مؤلف، عنــــان، الناثـــر، ســنة

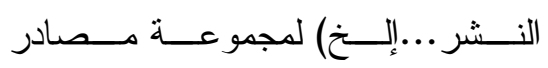

Jane Kessler and Mary K. Van Ullen, $\left({ }^{28}\right)$

"Citation Generators: Generating

Bibliographies for the Next Generation," The Journal of Academic Librarianship 31, no. 4

(July 2005): 310. 


$$
\begin{aligned}
& \text { المهيكلة المختلفة (منل } 21 \text { و MARC } \\
& \text { مخرجات المراجع المسترجعة: وذلك عـن } \\
& \text { XML و و BibTeX } \\
& \text { بر امج إدارة الاستــشهادات المرجعيــة ولة }
\end{aligned}
$$

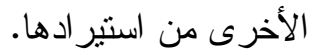

$$
\begin{aligned}
& \text { مشاركة مخرجات المراجـع : وذلــــــــن } \\
& \text { طريق: - ن } \\
& \text { • إنشاء مجمو عة مشاركة على أحد مو اقع } \\
& \text { بر امج إدارة الاستــشهادات المرجعيــة }
\end{aligned}
$$

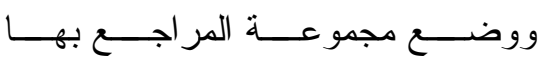

$$
\begin{aligned}
& \text { ل مشاركتها. } \\
& \text { • تصدير مجموعة المر اجع لملف ورفعسه }
\end{aligned}
$$

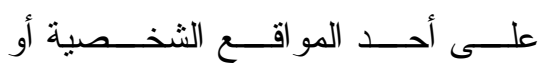

$$
\begin{aligned}
& \text { مجمو عات النقاش. } \\
& \text { • تصدير مجموعة المر اجع لملف و إرساله } \\
& \text { كمرفق بالبريد الإلكتروني. }
\end{aligned}
$$

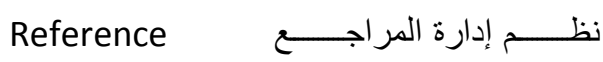

$$
\begin{aligned}
& \text { :Management Systems } \\
& \text { يمكن تعريف نظم إدارة المراجع علـى لـى } \\
& \text { أنها: أي طريقة منطقية لترتيب المر اجع.(r.) وقد }
\end{aligned}
$$

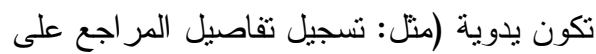

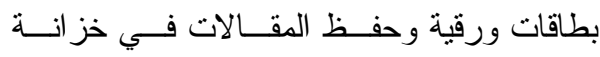

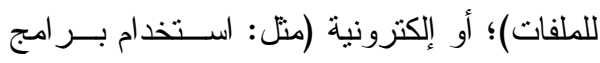

$$
\begin{aligned}
& \text { (تستخدم عملية تخصيص شكل المخرجات (تعديل } \\
& \text { نمط - إنثاء نمط جديد) لنتاسب منطلبات جهة } \\
& \text { النشر لعملية التوثيق. كما نستخدم أيضا لتعديل } \\
& \text { الأنماط لتناسب اللغة العربية. }
\end{aligned}
$$




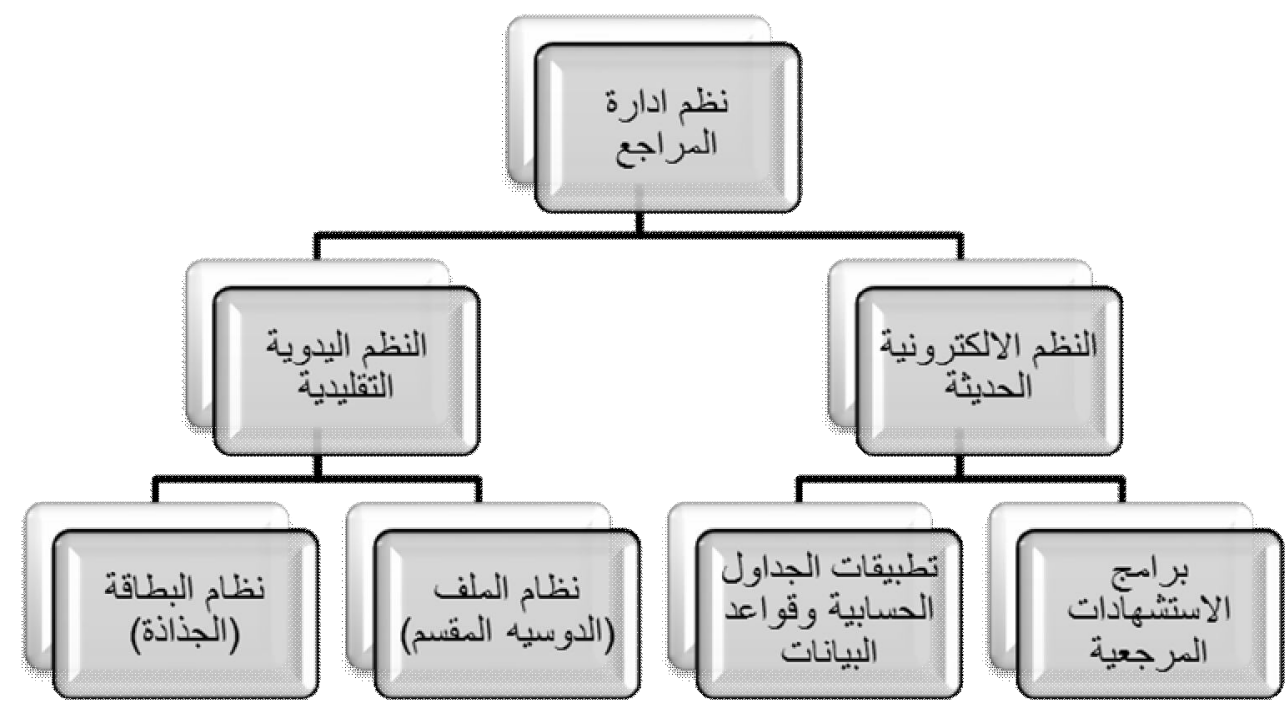

شكل رقم (1): نظم إدارة المراجع

المقياس الصغير لتدوين المصادر و المر اجع، و الوسط لتحليل المعلومات.

نظام الملف (الدوسيه المقسم): نزتب

المصادر و المر اجع على عدة أوراق ويكون

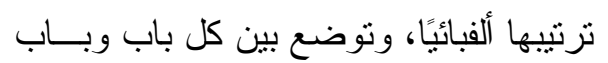

ورقة سميكة لها لسان بارز كتب على وجهه

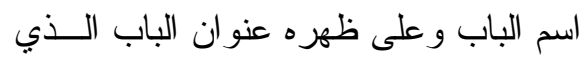
يليه، ولكل باب أور اق خاصة للاقتباسـات،

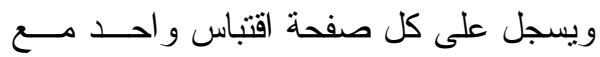

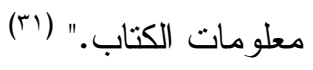

(11) محمد جمال طحان، "منهجية البحث نحو خلاصة، التربة

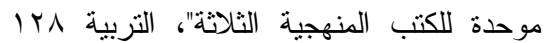

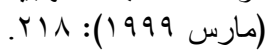

Manual الـــنظم اليدويـــــة التقليدايــــة

:Systems

ومن المعروف أن هنالك نظامين لجمع

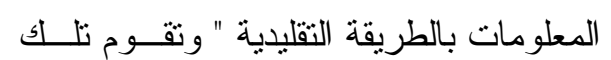
الأنظمة بترتيب قائمة المصادر وفق نسلسل بالفرله الأحرف الأبجدية لأسماء المؤلفين.

نظام البطاقة (الجذاذة): تكتب المـادة

المقتبسة على بطاقات ذات أحجام متـسـاوية، وتخصص كل بطاقة لاقتباس و احد وتـدون فيها معلومات الكتاب، وتوضع كل بطاقة في

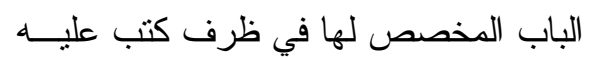
اسم الباب. و هناك مقاييس للبطاقة يكون عادة 
الكامل لتلك المر اجع، و البحث بأحد الحقــول

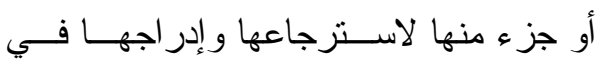

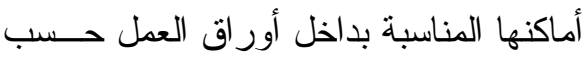

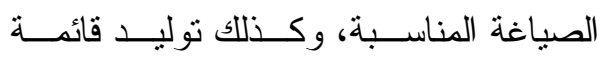
المر اجع بالصيغة المناســبة حسـب أنمــاط الاستشهادات المختلفة.

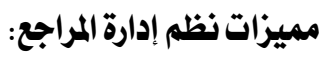

ولعل ما دفع إلى اللجـــوء لاســتخدام

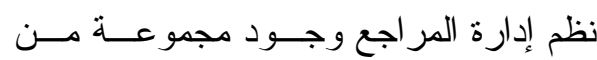
المميز ات لكل نظام من تلك النظم. مميزات النظام اليدوي لإدارة المراجع:

الآن بعد ما أصبح الحاسب الآلي في

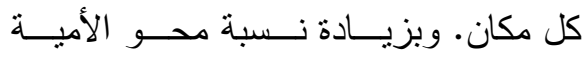

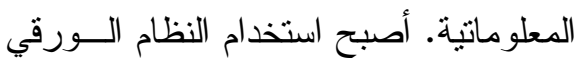
امر عاف عليه الزمن Outdated. ولكـن هناك عدد من الأسباب التي يمكن الأخذ بها

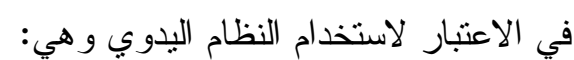
- النظام مصدم من قبل الباحــث و هكــــا يمكن أن يكون متلائم مع احتياجاته.

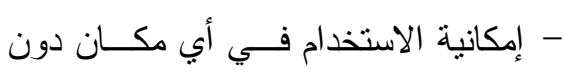
الحاجة لاستخدام حاسب آلي.

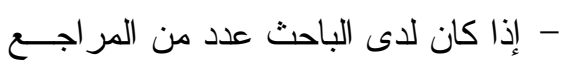

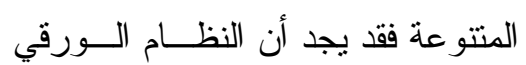
أسهل من الاضطر ار للتعرف على كيفية

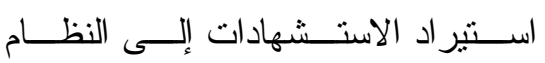
الإلكتروني.

\section{Electronic النظم الإكترونية الحديثـــة}

:Systems

تعتمد ثلاك الأنظمسـة علــى اســتخدام

الحاسب الآلي فــي إدارة وترتيــبـ و إنتـــاج

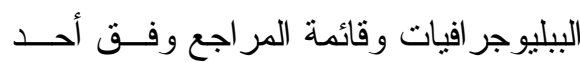
أنماط الاستشهادات المرجعية.

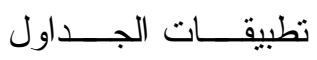
الحسابية وقو اعد البيانات:

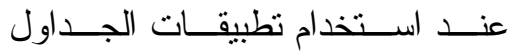
الحسابية منل برنامج Excel فيجب وضـــع

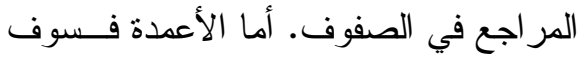

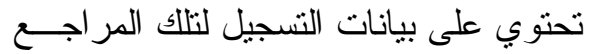

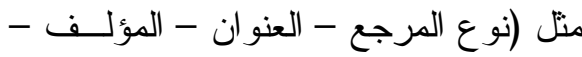
البيانات البيليوجر افية "الاستشهاد" - كلمـات

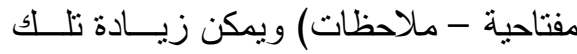
البيانات حسب احتياجات الباحث.

أما عند اســتخدام تطبيقــات قو اعــــ

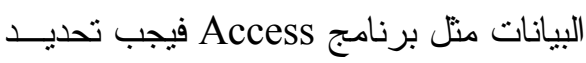
حقول "بيانات التسجيل" التي ير غب الباحـــ في وضعها قبل البدء في عمليــة التـسجيل. لوضع التصميم السليم لقاعدة البيانات. برامج إدارة الاستثهادات المرجعية:

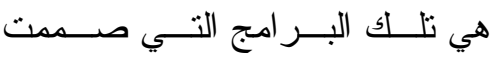

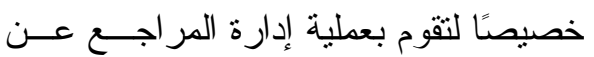

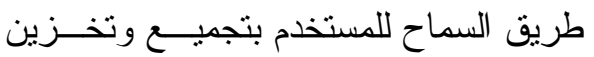
وتتظيم المر اجع، وتتيح بعضها إرفاق النص 
- سرعة استرجاع المقالات عـن طريــق

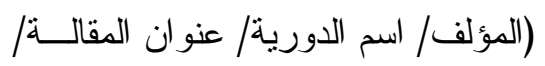

الكلمات المفتاحية/ الترقيم الدولي الموحد

للدورية ISSN/ معرف المقالة DOI).

أما في النظام البدوي التقليدي فلا يمكن

الاسترجاع إلا بأحد الطرق السابقة.

- إنتاج البحوث العلمية و البيليوجر افيـات

بطريقة سريعة ومباشرة (القدرة علــى لئى

إنتاج أنماط استشهاد وقائمة المر اجــع).

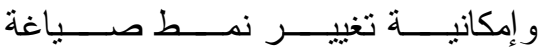

الاستشهادات لتتو افق مع نمــــ النـشـر

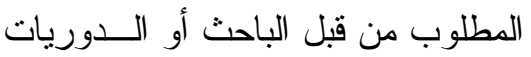

$$
\text { العلمية. }
$$

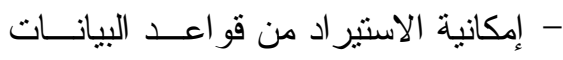

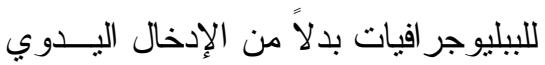

$$
\text { للبيانات البيليوجر افية. }
$$

- إمكانية مشاركة البيانات الببليوجر افيــة

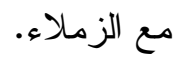

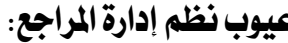

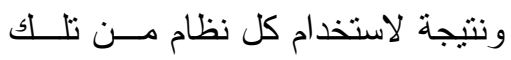
النظم، فقد ظهرت بعض العيوب.

عيوب النظام اليدوي لإدارة المراجع:

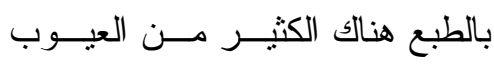

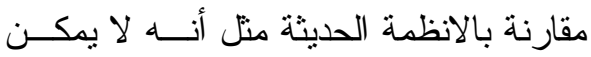

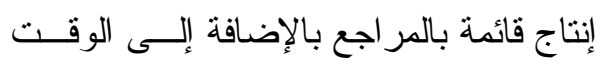

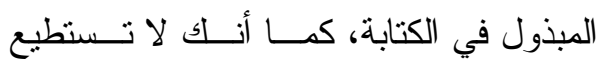

- لا داعي للقلق بـشنأن الحــصول علـىى

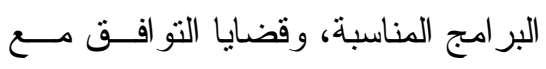

أنظمة النتغيل ومعالجات النصوص. أو أو

تعطل تلاك البر امج.

مميزات تطبيقات الجداول الحسابية وقواعد

البيانات لإدارة المر اجع: - المع

- إتاحة تطبيقات الجداول الحسابية وقو اعد

البيانات على نطاق و اســـع و لا حاجـــة

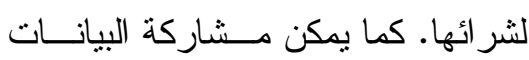

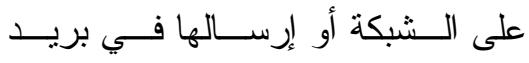
إلكتروني للزملاء.

- غالبًا ما نتوفر لدى المستخدم المهــار ات

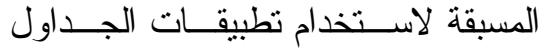

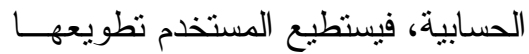

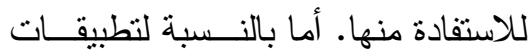

قو اعــــ البيانـــات فيحتـــاج المــــتخدم

لمهار ات متقدمة لنطوير نظام متكامل.

- خاصية البحث لتلــــ التطبيقــات تتــيح

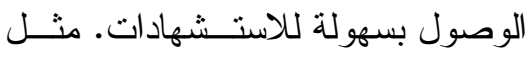

البحث بالمؤلف.

مميـــزات بــــر امج إدارة الاستـــشهادات

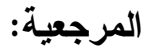

- رفع مستوى إدارة مجموعات المر اجع.

- سهولة تتظيم وتعقب المر اجع الجديــــة.

مثال "عند إضافة ملف النص الكامل". 
Direct Export بصياغات معياريــة تــستطيع بـــر امج إدارة الاستشهادات المرجعية التعامل معها. أو تقوم

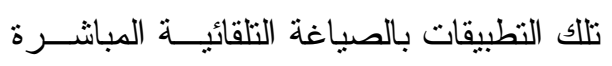

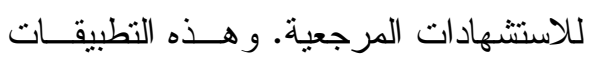
كالآتي: فهارس المكتبات: - الت تتيح معظم فهارس المكتبات الكبــرى

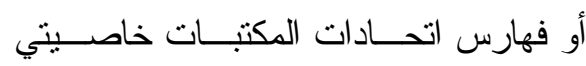
صياغة الاستشهاد أو تصديره لأحد بــر امج

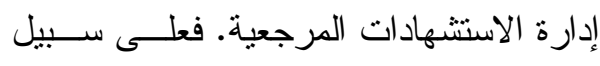
المثال يقدم موقع WorldCat خدمة صياغة

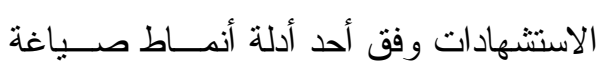

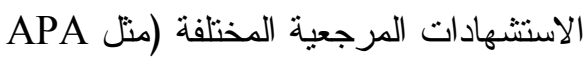
أو Chicago أو Harvard أو MLA أو Turabian بر امج إدارة الاستشهادات المرجعية المختلفة وخدية

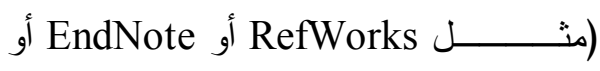

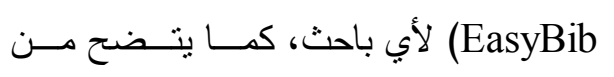

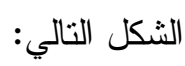

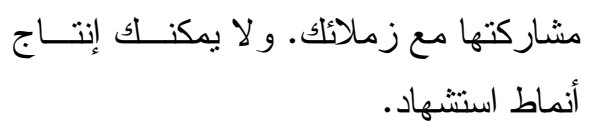

عيوب تطبيقات الجداول الحسابية وقواعـــ

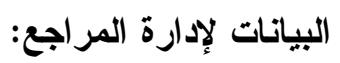

يجب أن نضع في الاعتبار أن هنــاك

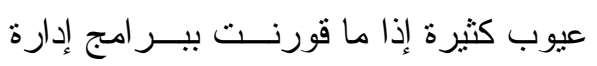

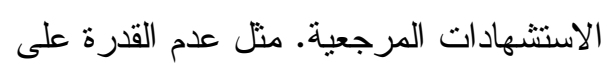
الاستير اد إلا عن طريق القص و اللصق حقل بحقل. وكذلك عدم القــدرة علــى الإنتـــاج التلقائي للمر اجع وفق نمط استشهاد. عيوب برامج إدارة الاستشهادات المرجعية: بالنسبة للبر امج التجارية: غلاء أسعار

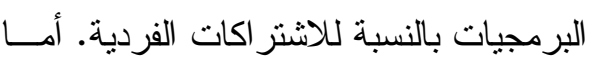

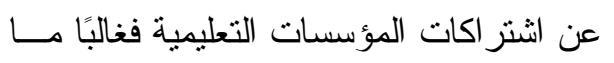
تحصل تللك المؤسـسـات علــى تــر اخيص

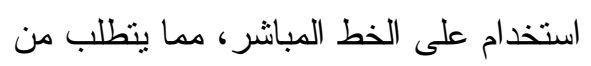

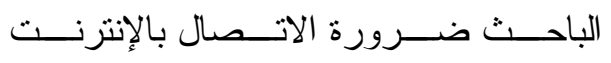

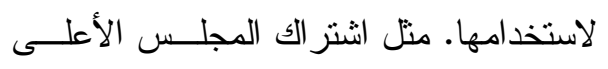
للجامعات ببرنــامج EndNote Web مـــع قاعدة بيانات ISI Web of Knowledge. كما ينطلب وجود البرنامج لــدى الـزملاء لمشار كة البيانات. تطبيقات الاستشهادات المرجعية: تعددت التطبيقات التي تخدم بـــر امج إدارة الاستشهادات المرجعية. حيث تقوم تلكك

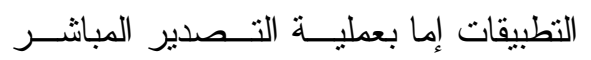




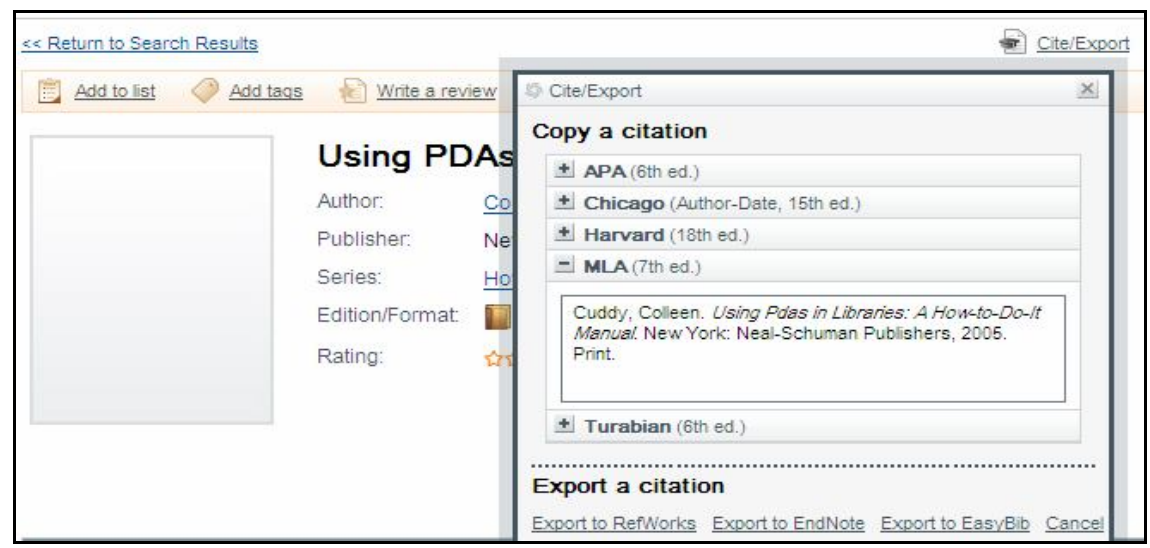

شكل رقم (ץ): خاصيتي صياغة وتصدير الاستثهادات في فهارس المكتبات

$$
\begin{aligned}
& \text { قائمة المر اجع أو تصدير ها دفعــة و احــدةً } \\
& \text { كما بتيح أيضًا بعد التسجيل و الدخول }
\end{aligned}
$$

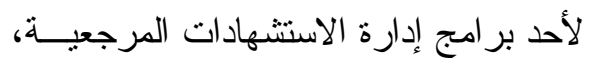

$$
\begin{aligned}
& \text { على الموقع إنثاء قائمة بالمر اجع لصياغتها } \\
& \text { كما يتضح من الثكل التالي: }
\end{aligned}
$$

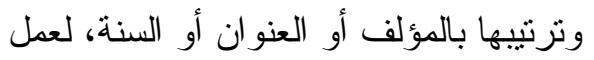

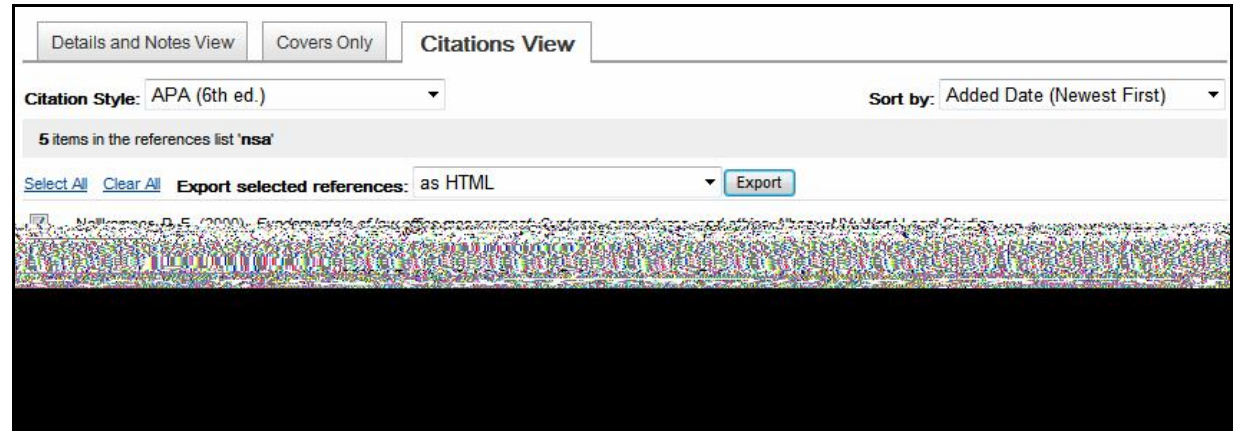

$$
\begin{aligned}
& \text { شكل رقم (ץ): إنثاء قائمة بالمر اجع أو تصدير ها دفعة } \\
& \text { واحدة لأحد برامج إدارة الاستثهادات المرجعية }
\end{aligned}
$$


الاستشهادات وفق أحد أدلة أنمـــاط صــياغة

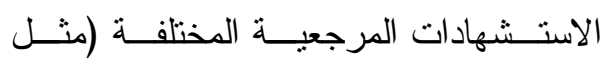

Chicago-Turabian أو APA أو AMA

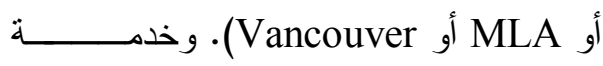
التصدير للاستشهاد عن طريق:

التصدير المباشر لاثثان مــن بـر امج

إدارة الاستشهادات المرجعية المبنيــة

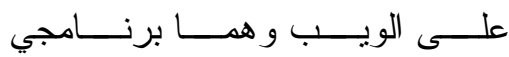

.EndNote Web g RefWorks

RIS) تصدير ملف بصياغات مهيكلة

.(MARC 21 ,

عرض الصياغات المهيكلة ) MARC

.(RIS, XML, BibTeX, 21

كما يتضح من الثكل التالي:
كما أن هناك بعض المكتبات الأخرى

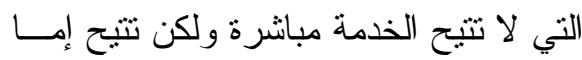

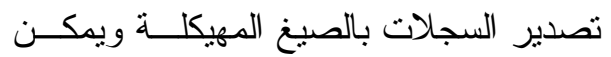

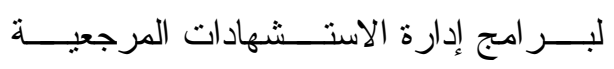

استير ادها بهذه الصيخ (مثل فهـرس الدرة الحســاد

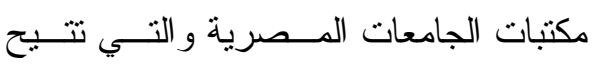

تصدير السجلات بـصيغة Marc 21 كمــاتس يتيح فهـرس Mirlyn لجامعسـة ميتـشجان التصدير بصيغة RIS). أو من خلال الربط فيط باستخدام بروتوكول Z39.50 و التي تسنطيع

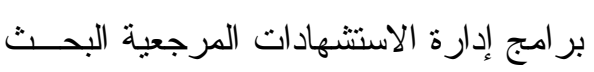

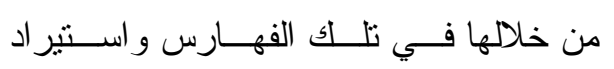

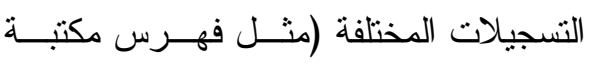
الكونجرس). وقد تتيح بعض الفهارس خدمة

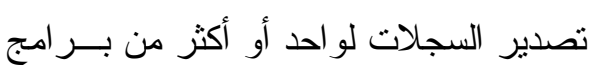

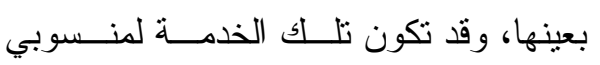
المكتبة فقط (rr). قواعد البيانات:

تتيح معظم قو اعد البيانات خاصـــيتي صياغة الاستشهاد أو تصديره لأحد بــر امج

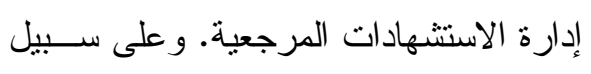
المثال فقو اعد EBSCO تتيح خدمة صياغة

(32) يتيح فهرس مكتبات جامعة جنوب فلوريدا خدمة لئرئ

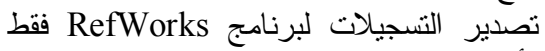
لأي باحث. بينما يتيح فهرس لبرن جامعة نورنتو

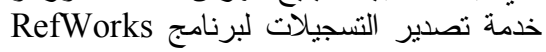
فقط لمنسوبي الجامعة. 


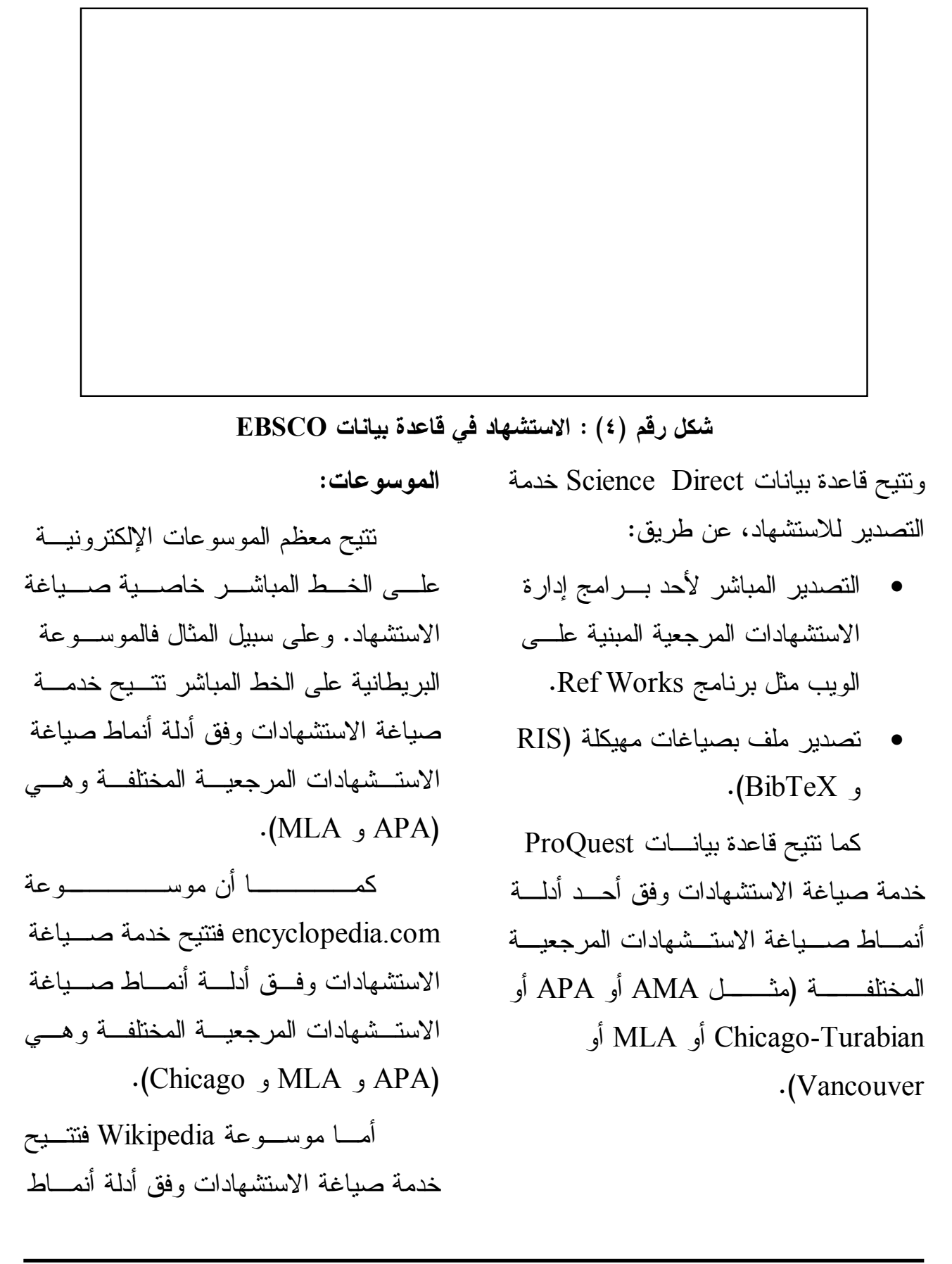


BibTeX

صياغة الاستشهادات المرجعية المختلفة وهي

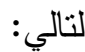

و MLA, Chicago و APA, AMA)

و Bluebook و MHRA , CSE

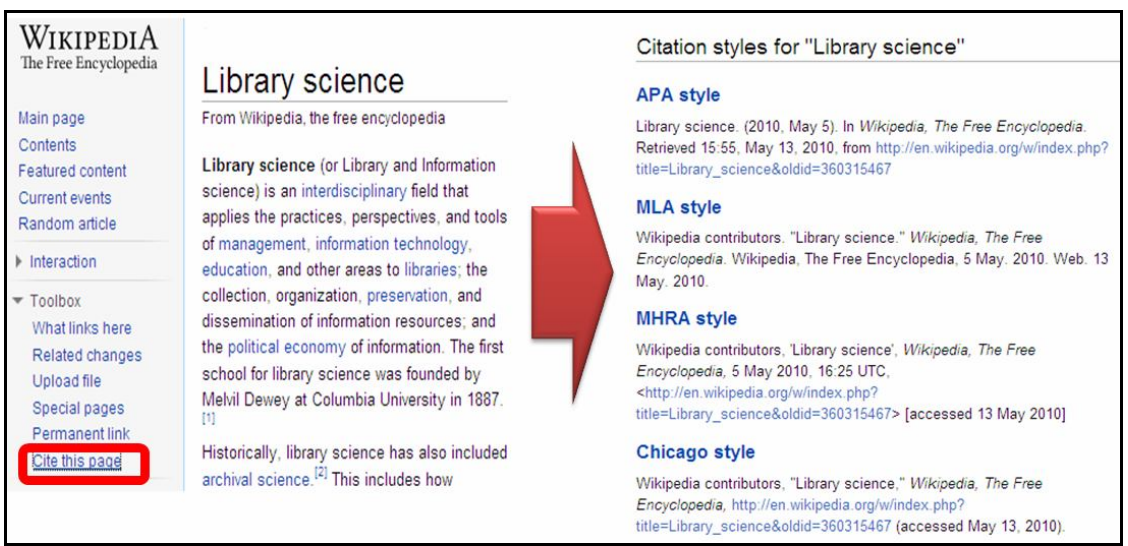

Wikipedia شكل رقم (0) : الاستشهاد في موسوعة

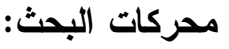

تتيح معظم محركات البحث الأكاديمية بر امج إدارة الاستشهادات المرجعية التاليـــة

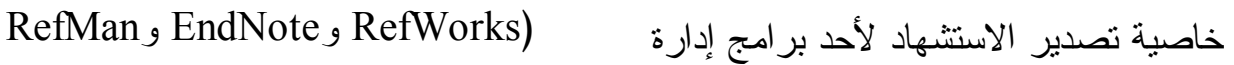

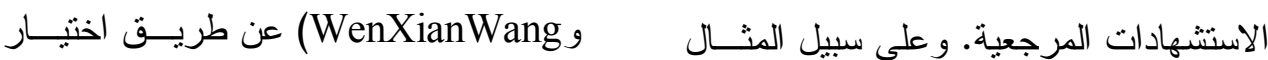

فمرك بحث Google scholar يتيح خدمة البرنامج من تقضيلات البحث، كما يت ضـح التصدير ملف للاستشهاد و الخــاص بأحسـد من الثكل التالي:

GOOgle scholar Preferences
Save your preferences when finished and return to search.
Scholar Preferences
Bibliography Manager $\quad$ Don't show any citation import links.
\[ \text { Show links to import citations into } \]

شكل رقم (†) : الاستشهاد في محرك بحث Google scholar 
الاستشهادات المرجعية. و على سبيل المثال

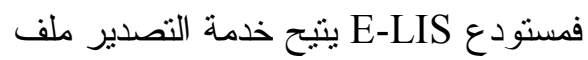

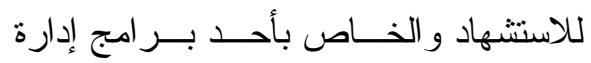
RefWorks) الاستشهادات المرجعية التالية بادئن

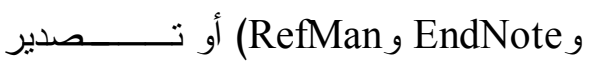

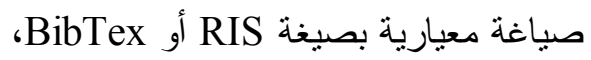
كما يتضح من الثكل التالي:
أما محرك بحث CiteSeerX فيتيح خدمة التصدير للاستشهاد عن طريق:

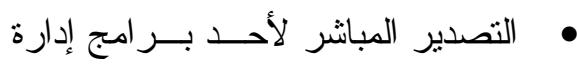

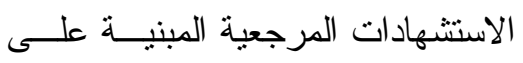

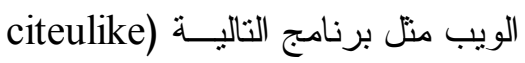

و (Bib Sonomy g connote)

$$
\text { • • عرض بصياغة مهيكلة (BibTeX). }
$$

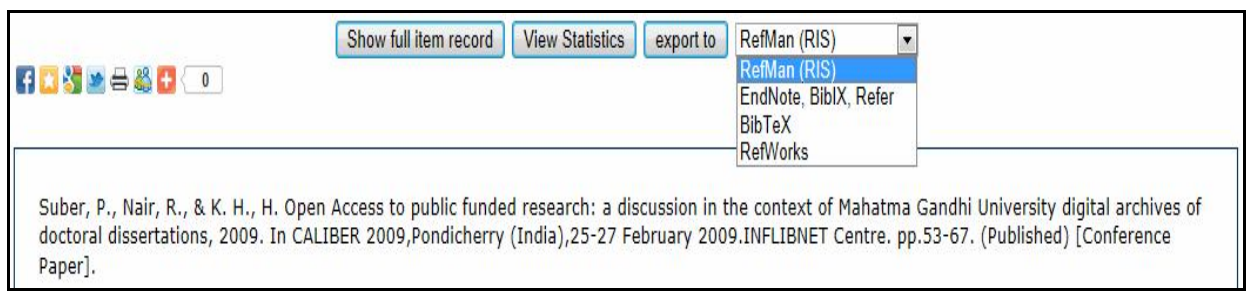

شكل رقم (V): الاستثهاد في المستودع الرقمي A-LIS

$$
\text { الـــصياغات المهيكاــــة لبــــرامج إدارة }
$$

برنامج لإدارة المر اجع لصياغة قائمة

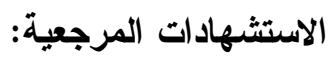

المر اجع. تستخدم أداة BibTeX مع برنامج لئرة

تستخدم جميع تلك الصياغات المهيكلة

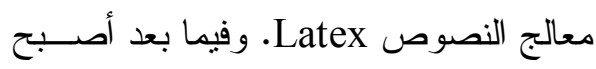

لتمكن بر امج إدارة الاستشهادات من تبـادل

BibTeX

$$
\text { • عن الصباغة: }
$$

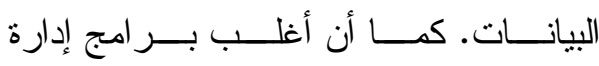

يبدأ المرجع برمز @ ثم يليـــهـــــــع

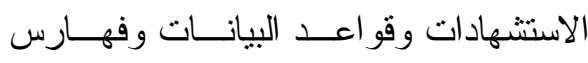

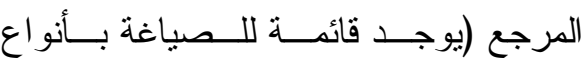

المر اجع). ثم رمز قوس المجموعة لثم الاسم

المكتبات تدعم تلك الصياغات لتقوم بتصدير

بيانات المر اجع بتلك الصباغات. BiBTEX الصياغة: *

الأخير و السنة (معرف المرجع) ثم علامـــة bib امتداد الملف: 


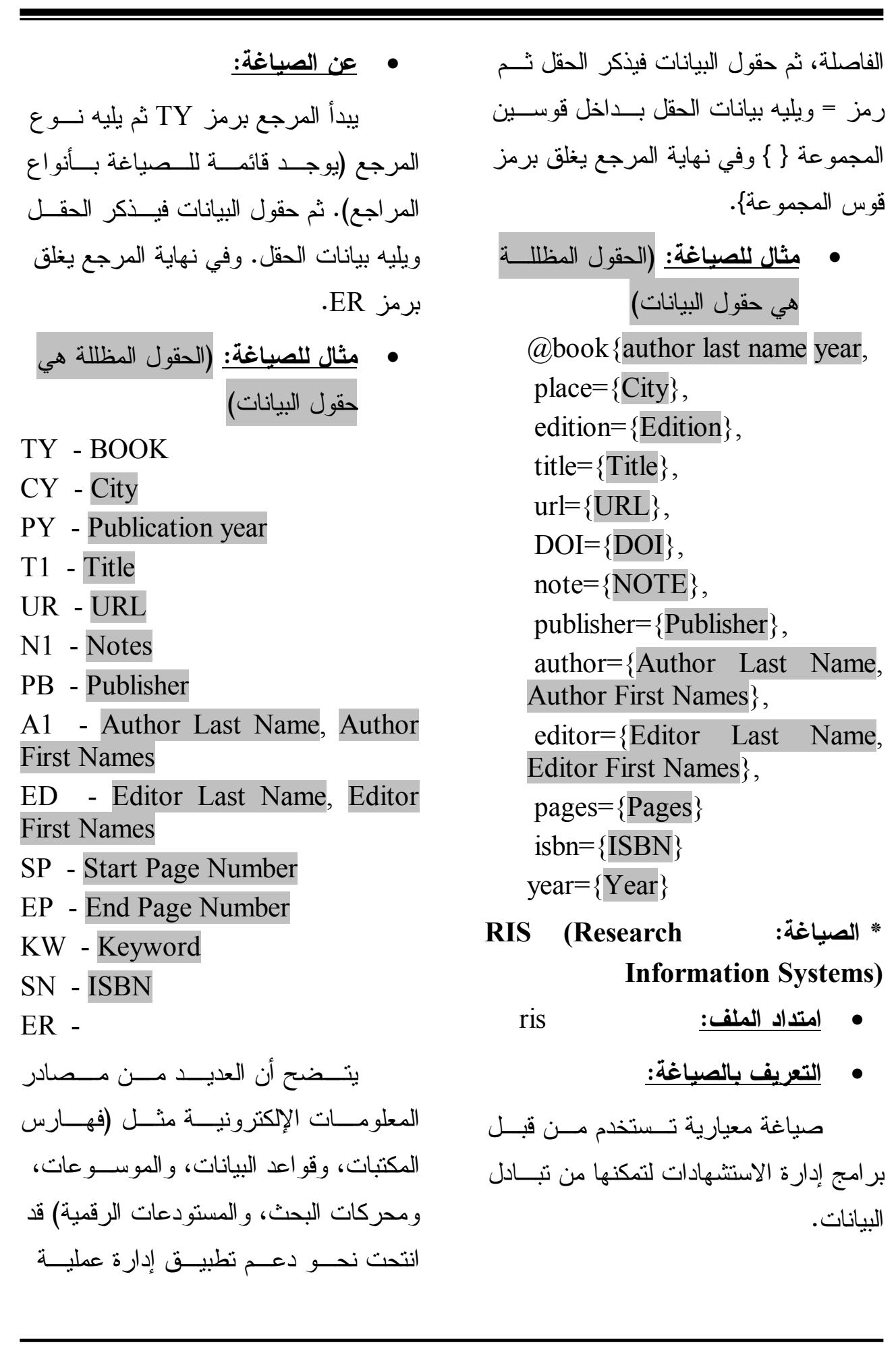


- ميمن تعريف بر امج إدارة الاستشهادات

Reference

Management Software

هي تلك البرامج التي صممت خصيصًا لتقوم بعملية إدارة المر اجع عن طريــق السماح للمـستخدم بتجميــع وتخــزين وتتظيم المر اجع، ونتيح بعضها إرفــاق

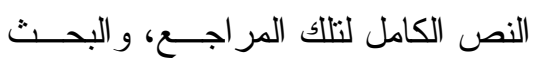
بأحد الحقول أو جزء منها لاسترجاعها و إدر اجها في أماكنها المناســبة بــــاخل أوراق العمل حسب الصبياغة المناســبة، وكذلك توليد قائمة المر اجـــع بالــصيغة المناسبة حــسب أنمــاط الاستــشهادات المختلفة.

تتعدد التطبيقات التي تخدم بر امج إدارة الاسنشهادات المرجعية. حيث ثقوم نلك التطبيقات إما بعملية التصدير المباثــر Direct Export المختلفة بصياغات معياريــة تـسنطيع بر امج إدارة الاستــشهـادات المرجعيــة

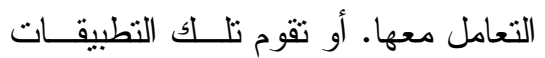
بالصياغة التلقائية المباشرة للاستشهادات المرجعية. و هذه التطبيقات هي (فهارس

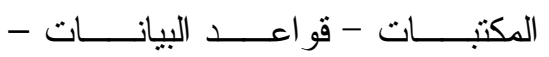
الموســوعات - محركــات البحـــث المستودعات الرقمية).
الاستشـهاداث المرجعية للأبحاث و الدر اســـة العلمية. وكذللك ظهور صــياغات مهيكلــة كمعايير لصباغة الاستـشهادات المرجعيــة. ولألك تعــــ البــر امج المتخصــصة لإدارة

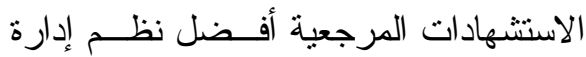
المر اجع لما تقدمه من مميز ات توفر الوقــت و المجهود المبذولين، وتشاير عمليــة إنتـــاج البحوث العلمية و الببليوجر افيــات بطريقــة سريعة ومباشرة (القدرة على إنتــاج أنمـــاط استشـهاد وقائمة المر اجع) . وكـــذلك إمكانيــة تغيير نمط صياغة الاستشهادات لتتو افق مع نمط النشر المطلوب مــن قبــلـ الباحــث أو

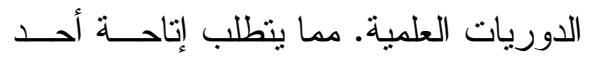
بر امج إدارة الاستشهادات المرجعية المفتوحة المصدر للباحثين باللغة العربية.

\section{نتائج الدراسة:}

\section{أظهرث الدراسة النتائج التالية:}

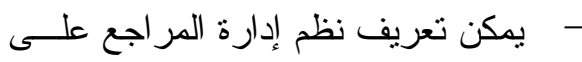

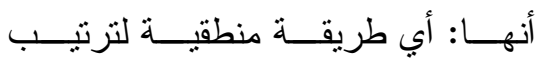

المر اجع. وقد تكون يدوية (منل: تسجيل

تفاصيل المر اجع على بطاقـات ورقيــة

وحفظ المقالات في خز انة للملفات)؛ أو إلكترونيــة (مثـــل: اســتخدام بـــر امج

متخصصة لإدارة المر اجع، أو استخدام

Excel تطبيقات الجداول الحسابية منل

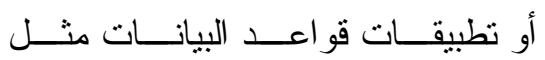
Access 


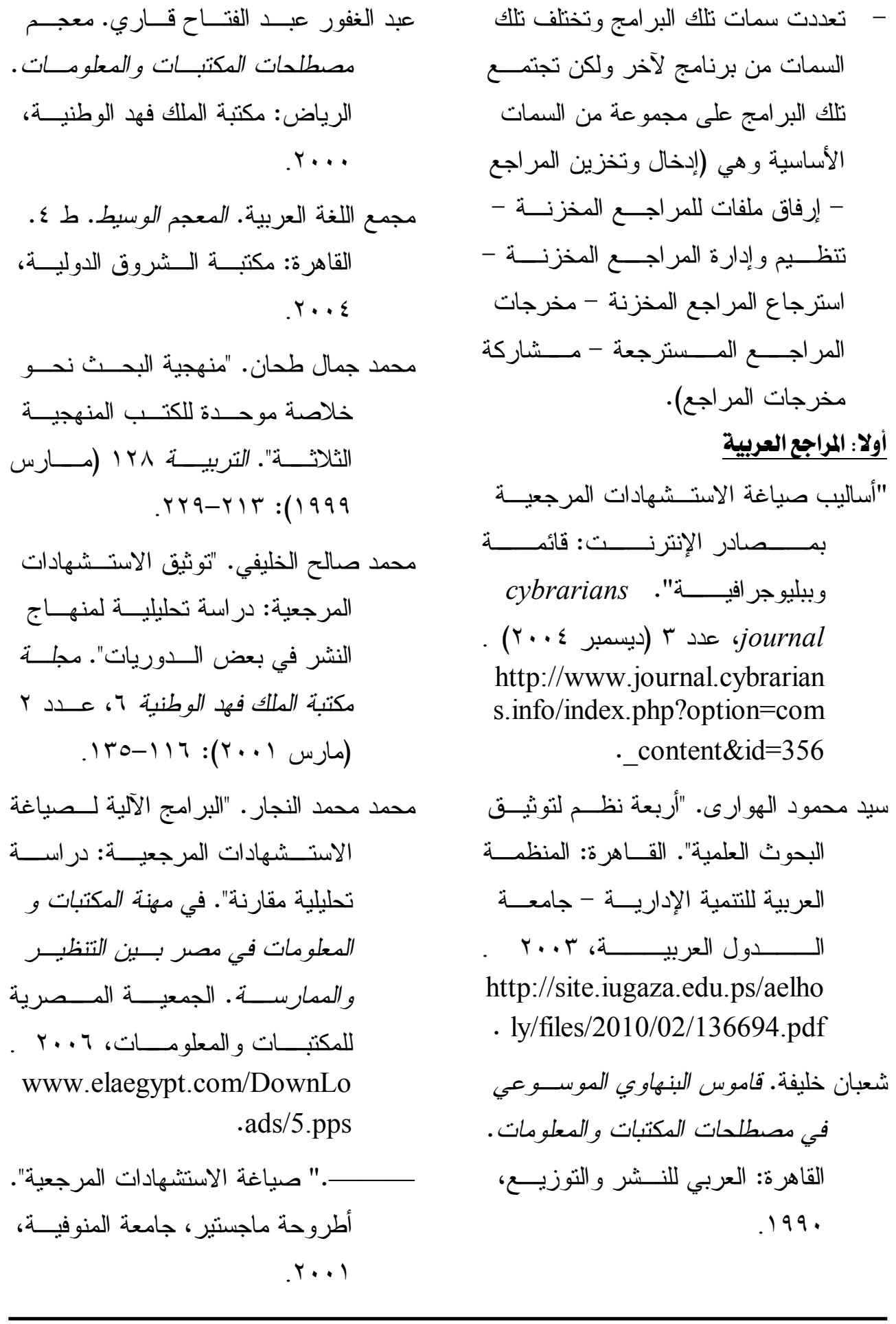

$11 \leqslant V$ 
Analysis and Comparison of Some Packages", 2010. http://www.burioni.it/forum/ dellorso/bmsdasp/text/index.html.

Gilmour, Ron, and Laura Cobus-

Kuo. "Reference

Management Software: A Comparative Analysis of Four Products." Issues in Science and Technology Librarianship, no. 66 (2011). http://www.istl.org/11summer/refereed2.html.

Gurney, Jud W., and Robert S. Wigton. "Computerized Reference Management: Searching the Literature." American Journal of Roentgenology $\quad 147$ (September 1986): 641-645.

Kessler, Jane and Ullen, Mary K. Van. "Citation Generators: Generating Bibliographies for the Next Generation," The Journal of Academic Librarianship 31, no. 4 (July 2005): 310 .

Moore, C. "Personal Reference Management Software-how to Evaluate It?" Health Libraries Review 8, no. 1 (1991): 4-10.

Neal, P. R. "Personal Bibliographic Software Programs: A Comparative Review." BioScience 43, no. 1 (1993): 44-51.
ثانيا : المراجع الأجنيية

Alligood, Elaine, Becky Skidmore, and National Information Center on Health Services Research and Health Care Technology. "Etext on Health Technology Assessment (HTA) Information Resources", July 2003.

http://www.nlm.nih.gov/archi ve/20060905/nichsr/ehta/cha pter17.html.

Beverley, Catherine, Andrew Booth, Louise Falzon, Colin Lynch, and Angie Rees. "Managing References". The NIHR Research Design Service for Yorkshire \& the Humber, 2007. http://rdseastmidlands.nihr.ac.uk/resou rces/doc_download/6managing-references.html.

Castilla, Liuris Rodríguez. "Le Resulta Difícil Hacer La Bibliografia: Los Gestores De Referencias Bibliográficas Pueden Ayudarlo." Acimed 19, no. 2 (February 2009): 1-21.

Dell'Orso, Francesco. "Bibliography Formatting Software: An Evaluation Template", 2007. http://www.burioni.it/forum/ ors-bfs/text/index.html.

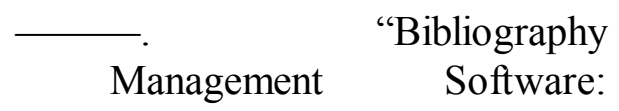




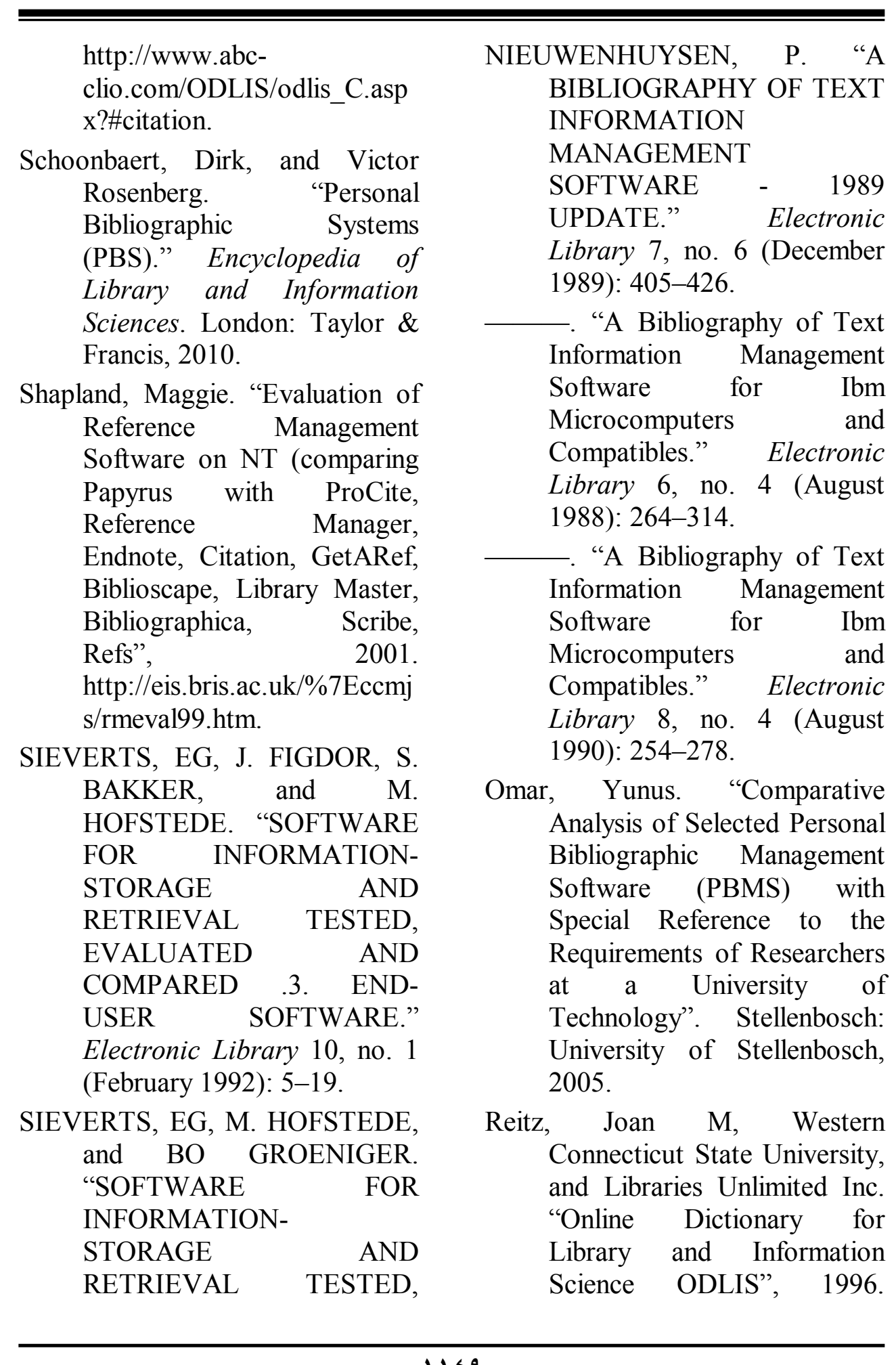




\begin{tabular}{|c|c|}
\hline Library 10, no. 6 (December & EVALUATED \\
\hline 1992): 339-357. & COMPARED \\
\hline SIEVERTS, EG, M. HOFSTEDE, & INDEXING AND FULL- \\
\hline A. NIEUWLAND, C. & TEXT RETRIEVAL \\
\hline GROENEVELD, and B. & PROGRAMS." Electronic \\
\hline DEZWART. "SOFTWARE & Library 10, no. 4 (August \\
\hline FOR INFORMATION- & 1992): 195-208. \\
\hline STORAGE AND & SIEVERTS, EG, M. HOFSTEDE, \\
\hline RETRIEVAL TESTED, & PH HAAK, \\
\hline EVALUATED AND & NIEUWENHUYSEN, GAM \\
\hline COMPARED .6. VARIOUS & SCHEEPSMA, L. VEEGER, \\
\hline ADDITIONAL & and GC VIS. "SOFTWARE \\
\hline PROGRAMS.” Electronic & FOR INFORMATION- \\
\hline Library 11, no. 2 (April & STORAGE $\quad$ AND \\
\hline 1993): 73-91. & RETRIEVAL \\
\hline SIEVERTS, EG, and $\mathrm{M}$. & EVALUATED \\
\hline HOFSTEDE. "SOFTWARE & COMPARED $\quad .2$. \\
\hline FOR INFORMATION- & CLASSICAL RETRIEVAL- \\
\hline STORAGE AND & SYSTEMS.” Electronic \\
\hline RETRIEVAL TESTED, & Library 9, no. 6 (December \\
\hline EVALUATED AND & 1991): 301-318. \\
\hline COMPARED .1. GENERAL & SIEVERTS, EG, M. HOFSTEDE, \\
\hline INTRODUCTION." & G. LOBBESTAEL, BO \\
\hline Electronic Library 9, no. 3 & GROENIGER, $\quad$ F. \\
\hline (June 1991): 145-154. & PROVOST, and P. SIKOVA. \\
\hline —. "SOFTWARE & "SOFTWARE $\quad$ FOR \\
\hline INFORMATION- & INFORMATION- \\
\hline STORAGE & STORAGE \\
\hline RETRIEVAL & RETRIEVAL \\
\hline EVALUATED AND & EVALUATED \\
\hline COMPARED .7. WHAT TO & COMPARED \\
\hline CHOOSE, OR THE & PERSONAL \\
\hline PURPOSE OF IT ALL." & INFORMATION \\
\hline Electronic Library 12, no. 1 & MANAGERS, \\
\hline (February 1994): 21-22. & HYPERTEXT \\
\hline & RELEVANCE \\
\hline & PROGRAMS." \\
\hline
\end{tabular}

